\title{
Gêneses urbanas do colonialismo: síntese de encontros culturais
}

\begin{abstract}
Rubens Gianesella ${ }^{1}$
RESUMO: Investigações sobre a gênese das vilas litorâneas de Cananeia, Iguape, São Vicente, Santos, São Sebastião e Ubatuba, no atual estado de São Paulo, evidenciam a significativa contribuição das sociedades indígenas nas ocupações do colonialismo. Presentes alguns séculos antes da chegada dos europeus, elas elegeram essa frente atlântica como habitat, estabelecendo em nichos ecológicos seus lugares de vivência. Tais escolhas balizaram as futuras instalações. Uma recorrência simboliza o encontro cultural entre indígenas e europeus: a articulação do módulo espacial da Matriz com a contiguidade da "rua direita".

PALAVRAS-CHAVE: Encontro cultural. Indígenas. Nichos ecológicos. Colonialismo. Gênese urbana.
\end{abstract}

ABSTRACT:Research about the genesis of the coastal towns of Cananea, Iguape, Sao Vicente, Santos, Sao Sebastiao and Ubatuba, in the current state of Sao Paulo, demonstrates the significant contribution of indigenous societies to colonial occupation. These communities were here a few centuries before the Europeans arrived. They chose the Atlantic coast as their habitat, establishing their settlements in particular ecological niches. These choices were used as guidelines for the new colonial towns. A recurring process symbolizes this cultural encounter between indigenous and Europeans: the positioning of the new churches in line with well established indigenous rights of way.

KEYWORDS: Cultural encounter. Indigenous. Ecological niches. Colonialism. Urban origins.

Introdução

No quarto centenário da capital paulista, o antropólogo Egon Schaden informava: "Os colonos lusos que em 1532 vieram a São Vicente em companhia de Martim Afonso de Sousa não encontraram aqui uma terra desabitada" 2 . $\bigcirc$ trecho, por sua conotação, parece surpreender os leitores com uma realidade

\footnotetext{
1. Doutorando em História e Fundamentos da Arquitetura e do Urbanismo, Faculdade de Arquitetura e Urbanismo da Universidade de São Paulo, sob orientação de Beatriz Piccoloto Siqueira Bueno. E-mail: <rubensgianesella@ gmail.com $>$.

2. Cf. Egon Schaden (1954, p 386); extraído originalmente de um artigo publicado em 25 jan.1954, no jornal $O E s$ tado de São Paulo.
} 
3. Sob o título Paisagens no tempo: vilas litorâneas paulistas; em 2008, na Faculdade de Arquitetura e Urbanismo da Universidade de São Paulo.

4. Os cronistas do século XVI, com os registros de seus olhares, colaboraram com nossas investigações. Além da história do Brasil e do urbanismo, intrínsecos, $\mathrm{e}$ das adiante citadas geografia e arqueologia, observamos estudos pertinentes de sociologia, antropologia e de comunicação ambiental.

5. Cf. Peter Burke (2005, p. 155). obscura de seu passado. De fato, para o repertório comum do nosso conhecimento, a história brasileira tem início com a descoberta de nossas terras pelos portugueses. Alguns índios viviam aqui, sem dúvida, mas nunca mais se ouviu falar deles. Quando muito, foram tratados como coadjuvantes de nossa história. Schaden, no entanto, mais do que alertar sobre a importância dos domínios pregressos, destaca a pluralidade étnica que ocupava áreas do atual estado de São Paulo. Da mesma forma, diversos autores - de cronistas e jesuítas do século XVI chegando a pesquisadores atuais na área das ciências humanas - esmeraram-se em caracterizar os habitantes primitivos dessa região.

Ao iniciarmos nossa pesquisa de Mestrado com o propósito de investigar o universo de imagens, representações e processos históricos que nortearam a urbanização do litoral paulista, especialmente em sua gênese ${ }^{3}$, notamos que, sem a multidisciplinaridade das ciências sociais, não conseguiríamos a aproximação pretendida desse recorte histórico ${ }^{4}$. Entre outras áreas, fontes da geografia humana, diferenciando, por exemplo, lugares de vivência e espaços físicos, em sintonia com os elos afetivos que ligam as pessoas aos seus lugares - temáticas comunicacionais e ambientais do campo das percepções contribuíram para valorizarmos os povos indígenas enquanto vertente significativa na formação da sociedade brasileira. Se as produções urbanas são processos sociais, e se os contatos euro-indígenas foram tão estreitos nos primórdios da colonização, as representações dos espaços construídos nas localidades e nas suas articulações revelam, necessariamente, a dinâmica interétnica que se desenhou a partir daquele encontro cultural quinhentista. Segundo Peter Burke, historiador cultural inglês,

a expressão "encontros culturais" passou a ser usada em substituição à palavra etnocêntrica "descoberta", especialmente a partir de 1992, com as comemorações dos 500 anos do desembarque de Colombo nas Américas. Ela está associada a novas perspectivas na história, dando atenção tanto à "visão dos vencidos", como chamou o historiador mexicano Miguel León-Portilla, como à visão dos vencedores ${ }^{5}$.

De fato, a partir dos contatos, nunca mais as sociedades envolvidas, entre dominados e dominadores, foram as mesmas. Novas expressões, todavia, não aniquilam o passado. Ao contrário, enquanto se reestruturam, elas perpetuam os repertórios culturais de suas vertentes. Portanto, nesse cenário, os indígenas não foram apenas coadjuvantes. Houve, na região vicentina le em toda a Colônia), uma inquestionável interação cultural entre os poucos colonos portugueses e milhares de Tupis (especialmente), sem a qual os ádvenas não sobreviveriam ou não lograriam êxito na fixação de suas primeiras instalações, rurais e urbanas.

A implantação de vilas e cidades no Novo Mundo sempre foi, para a historiografia, resposta da interdependência das Colônias face à expansão mercantilista europeia. Em consequência, os estudos sobre a urbanização fundamentados nos aspectos estruturais e econômicos da ldade Moderna têm essas povoações como produto cultural exclusivo dos grupos dominadores. 
Todavia, esses modelos tradicionais de análise podem, pela generalização, macular a percepção e a identificação das especificidades sociais inerentes às suas gêneses, das quais são representações. Muito pouco se investigou sobre as sociedades pré-coloniais que, invariavelmente, ocupavam os mesmos locais onde se estabeleceram os aglomerados. Se pretendermos nos aproximar desse contexto histórico, merecem investigação as evidências de sua contribuição na gestão não só das vilas, mas de toda rede urbana do colonialismo. Presentes alguns séculos antes da chegada dos europeus, indígenas de tronco Tupi, predominantes, elegeram a frente atlântica brasileira como habitat, estabelecendo em nichos ecológicos ${ }^{7}$ suas identidades, estreitamente harmonizadas com o meio ambiente. Essas escolhas pregressas balizaram as instalações estrangeiras advindas. Os mesmos sítios, antes ocupados por aldeias (grupos locais) ou acampamentos, foram sequenciados pela arquitetura de raiz ibérica. Em resposta aos novos filtros culturais, houve uma inegável superposição nos espaços construídos. O historiador Sérgio Buarque de Holanda, em Raízes do Brasil, acena com a constatação:

E é significativo que a colonização portuguesa não se tenha firmado ou prosperado muito fora das regiões antes povoadas pelos indígenas da língua-geral. Estes, dir-se-ia que apenas prepararam terreno para a conquista lusitana. Onde a expansão dos Tupi sofria um hiato, interrompia-se também a colonização branca ${ }^{8}$.

No I Seminário Cananeia tem história, realizado nessa cidade em setembro de 2005, a arqueóloga Maria Cristina Scatamacchia - ao responder à questão "em quais sítios de núcleos urbanos históricos da região foram evidenciados sinais de presença indígena anterior?" - foi enfática: "Em todos!"9

A origem das vilas estudadas, antecedente ou não de sua constituição jurídica, corresponde, na maioria das vezes (com particularidades em Cananeia, Iguape, São Vicente e Ubatuba), ao evento que arqueólogos denominam "contato euro-indígena" 10, ocorrido no século XVI. Dessa forma, podemos associar tal embrião à dinâmica social desencadeada a partir daquele encontro interétnico. Todavia, a sutileza das representações dessa arquitetura urbana incipiente é superada pelo significado de sua inserção ambiental. A partilha dos mesmos sítios, dos mesmos lugares de vivência, dos mesmos atrativos ecológicos vitais à sobrevivência dos europeus que gradativamente foram chegando, selou o destino dos futuros enquadramentos sociais. A arquitetura portuguesa decerto vai instalarse, notadamente simplória, na capitania vicentina nos primeiros séculos. Mas foram as ocupações pregressas que designaram a sorte da evolução urbana subsequente. Seculares, elas sinalizaram com a sustentabilidade que permitiu a consolidação da sociedade colonial na região.
6. O conceito de rede urbana foi discutido oportunamente pelo Prof. Dr. Nestor Goulart Reis Filho: "Sendo o fato urbano uma decorrência direta do processo de urbanização, seu estudo deve tomar como ponto de partida a rede urbana, que é o conjunto das respostas às solicitações do processo.A significação dos núcleos ou de suas partes só pode ser compreendida quando referida ao contexto mais amplo, que é a rede"; cf. Nestor Goulart Reis Filho (1968, p.78)

7.Habitat e nicho ecológico são assim conceituados pelo zoólogo norte-americano Eugene P. Odum: "O termo babitat é profusamente utilizado, não apenas em ecologia mas por toda a parte Geralmente considera-se que significa o lugar onde vive um organismo [... Ou uma] comunidade completa."; cf. Eugene P. Odum (2004, p 376). "O nicho ecológico, por outro lado, é um termo com maior âmbito, que inclui não apenas o espaço físico ocupado por um organismo, mas também o seu papel funcional na comunidade $[. .$.$] .$ Consequentemente, o nicho ecológico de um organismo depende não apenas do sítio onde vive mas também daquilo que faz (como transforma energia, se comporta, responde ao seu ambiente físico e biótico e o modifica). [...] Por analogia, pode dizer-se que o habitat é a 'morada' do organismo e que o nicho é a sua 'profissão', biologicamente falando";idem,p. 375.

8. Cf. Sérgio Buarque de Holanda (1971, p. 72).

9.Ver Maria Cristina Mineiro Scatamacchia (2005).

10. Ver Maria Cristina Mineiro Scatamacchia e Dorath P Uchôa (1993). 
11. Cf. Darcy Ribeiro (1995, p. 31); grifo nosso.

12. Esse núcleo corresponde à região das vertentes dos rios Guaporé e Madeira, no atual estado de Rondônia.

13. Cf. Maria Cristina Mineiro Scatamacchia (1990, p. 97); grifo nosso.

14. José Joaquim J. P. Brochado (1984,p. 564); apud Maria Cristina Mineiro Scatamacchia (1990, p. 97).
A caminho do mar

Antes que ocupassem essa frente atlântica e encontrassem um desafio ainda maior, desta vez insuperável - a dominação portuguesa -, longos caminhos foram trilhados pelos povos de tronco Tupi. $\bigcirc$ antropólogo Darcy Ribeiro elucida:

Os grupos indígenas encontrados no litoral pelo português eram principalmente tribos de tronco tupi que, havendo se instalado uns séculos antes, ainda estavam desalojando antigos ocupantes oriundos de outras matrizes culturais. Somavam, talvez, 1 milhão de índios, divididos em dezenas de grupos tribais, cada um deles compreendendo um conglomerado de várias aldeias de trezentos a 2 mil habitantes (Fernandes 1949). Não era pouca gente, porque Portugal àquela época teria a mesma população ou pouco mais ${ }^{11}$.

A arqueóloga Maria Cristina Mineiro Scatamacchia, em sua tese de Doutorado, antes de caracterizar as áreas de distribuição do complexo cultural Tupi-Guarani, faz uma consideração metodológica:

Um dos objetivos da tese é demonstrar que o que foi impropriamente denominado Tradição Tupiguarani constitui, na realidade, duas extensões distintas da Tradição Policrômica Amazônica no leste da América do Sul, que pode ser dividida em duas subtradições culturais distintas, a Guarani e a Tupinambá. Estas duas subtradições, partindo de um núcleo comum ${ }^{12}$, teriam se desenvolvido paralelamente a partir de sua separação há pelo menos 2000 anos $^{13}$.

A seguir, a autora cita, de outro pesquisador, trecho elucidativo sobre a dinâmica dos percursos dos povos indígenas anteriores ao período dos contatos, que transcrevemos:

Ainda no início da era cristã, dois ramos de uma cultura tipicamente amazônica invadiram o leste da América do Sul [...] Pelo ano 100, a cultura ou subcultura Guarani já se encontrava bem estabelecida no sul do Brasil e, ao redor do ano 500, a cultura ou subcultura Tupinambá, uma versão atenuada da cultura Marajoara, chegou ao nordeste do Brasil. A expansão para leste da cultura Guarani no sul do Brasil foi lenta e se desenvolveu em vagas sucessivas, cada vez cobrindo áreas maiores de território. A expansão da cultura Tupinambá para o sul foi, pelo contrário, rápida e linear, movendo-se ao longo da estreita faixa costeira. Cerca de quinhentos anos antes da chegada dos europeus, as duas mandíbulas das frentes de expansão Guarani e Tupinambá se chocaram finalmente numa fronteira situada ao sul do curso do Tietêt $^{14}$.

Nosso recorte de estudo - a frente atlântica da capitania de São Vicente - envolve, especialmente, o enquadramento das sociedades agricultorasceramistas de subtradição Tupinambá. Algumas etnias de caçadores-coletores, em menor expressão demográfica, permeavam essa área, notadamente no Vale do Paraíba. Mas, registradas em diversas fontes etno-históricas dos séculos XVI e XVII, 
eram tribos Tupiniquim (no planalto paulistano) e Tupinambá (no litoral fluminense) que, com seus assentamentos, predominavam nesses setores.

Ao observarmos os contornos e a redes periféricas das Áreas Metropolitanas de São Paulo e do Rio de Janeiro, pensamos o quanto dessa trajetória de sucesso se deve às escolhas antigas: suas áreas centrais nos remetem à localização das aldeias principais dos respectivos grupos tribais.

Resguardadas as especificidades das vertentes sociais do encontro cultural, importa-nos a constatação de que, nesse processo histórico, a ocupação pré-colombiana entre aldeias, acampamentos e trilhas foi apropriada, pela funcionalidade colonial, enquanto povoações, núcleos urbanos e caminhos - ou seja, pelo enquadramento espacial da rede urbana. As iniciativas do colonizador, bem sucedidas, não desqualificaram as antigas escolhas dos sítios, muito menos as vias de comunicação continental. Ao contrário, parece-nos que o mérito do colonizador português está em perceber que a assimilação das virtudes culturais primitivas favorecia seus anseios de conquista do novo mundo.
15. Podemos projetar as mesmas características e conceitos em outros cenários (senão em todos) do colonialismo brasileiro, respeitando evidentemente suas especificidades.

Nichos \& habitat

Na inserção das aldeias indígenas e dos núcleos coloniais no litoral vicentino, é recorrente um elenco de vetores ambientais ${ }^{15}$. Desde as populações

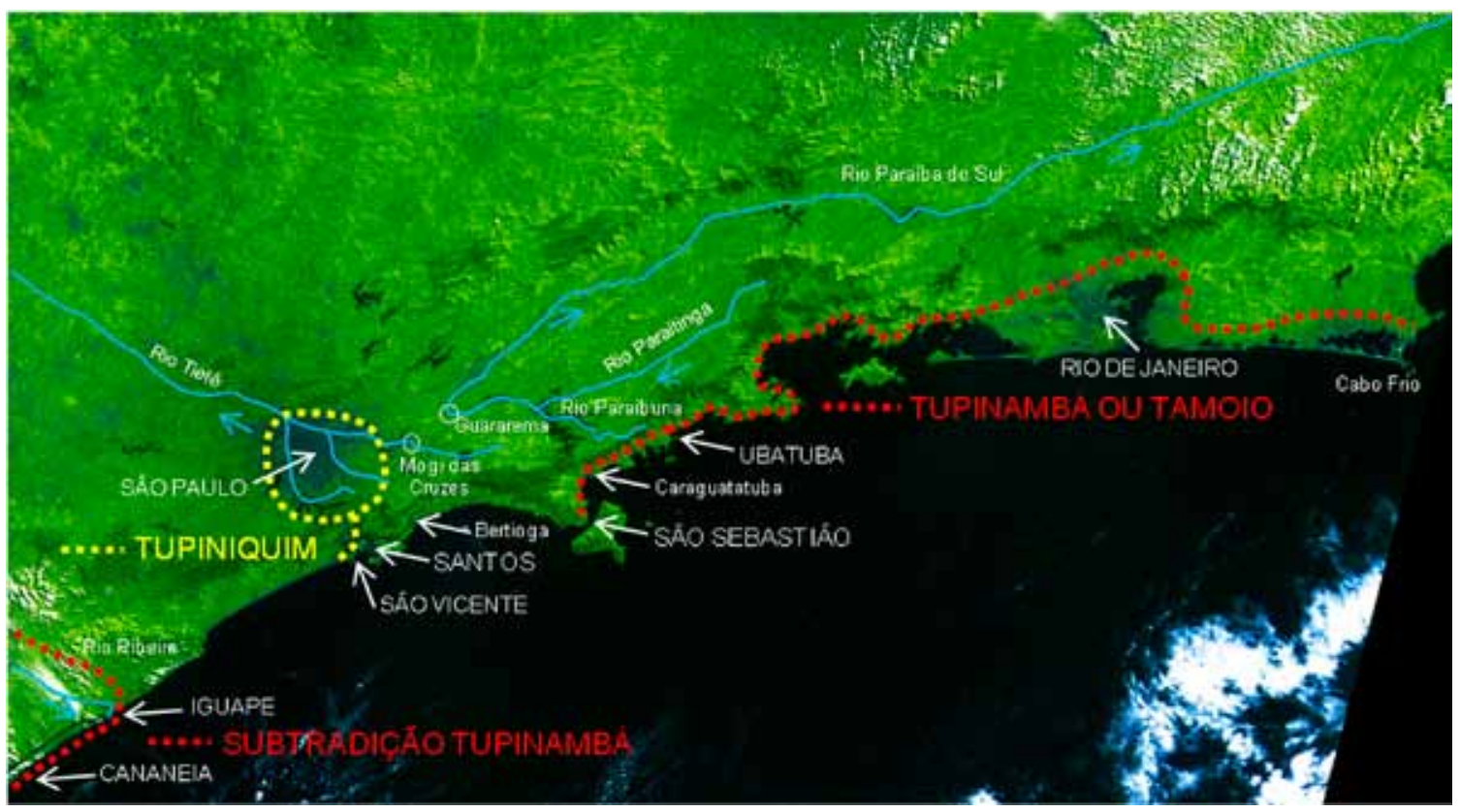

Figura 1 - Nossa frente atlântica: um quadro singelo das ocupações Tupi que assistiram a chegada dos europeus no século XVI, marcando para sempre a paisagem e os seus destinos. Infográfico elaborado pelo autor sobre mapa obtido por satélite. Fonte do mapa: Instituto Nacional de Pesquisas Espaciais, Sat. Cbers, 2000. 
16. Cf. André Prous (1992, p. 202).

17. Cf. Pedro Paulo Funari e Francisco Silva Noelli (2005, p. 86).

18. É notório que as sociedades indígenas detêm, até hoje, a sabedoria de não comprometer a transformação com os limites da degradação.

19. Cf.André Prous (1992, p. 200); grifo nosso. sambaquieiras, tais vetores são componentes indissociáveis da permanência humana em algumas localidades, como observa o arqueólogo André Prous:

O conjunto mais favorável à captação alimentar é o das enseadas, baías e lagunas, contato entre o ambiente marítimo e terrestre, entre a água salgada e [a] doce. [...] A penetração do ambiente marítimo dentro do continente torna vizinhos o campo, a mata e o mar, concentrando, num raio mínimo, recursos que, em geral, se acham separados ${ }^{16}$.

Já os historiadores e arqueólogos Pedro Paulo Funari e Francisco Silva Noelli, ao tratarem das sociedades agricultoras-ceramistas, de tronco Tupi, que ocuparam a mesma região alguns milênios depois, informam que "os assentamentos dos povos agricultores são comumente rodeados por uma série de locais menores, funcionando como áreas satélites, como os acampamentos nas roças, o porto das canoas, as áreas de extração de argila para cerâmica ou de pedras para confecção de artefatos e as áreas de coleta ou de caça"17.

É essa concentração de atrativos ambientais na mesma localidade que particulariza a composição física dos nichos ecológicos. Esse conceito, todavia, subentende a interatividade dos seres vivos nesse meio: seu modo de vida. Tais lugares de vivência pressupõem, portanto, uma dinâmica transformadora ${ }^{18}$. Há, entre as vilas litorâneas de Cananeia, Iguape, São Vicente, Santos, São Sebastião e Ubatuba - eleitas como fonte de estudo -, uma forte identificação com essa paisagem. Nessas áreas, pode ser elencado um feixe comum de componentes. A maior identidade, sem dúvida, está em seu agenciamento aos estuários marinhos mais significativos da costa. Os portais - dos rios e lagamares - mais expressivos em sua articulação com o oceano favorecem o afluxo, além dos cardumes lem seus ciclos de procriação), e das navegações em demanda de seus terminais. A apropriação dos portos naturais simboliza a interação cultural: pontuavam as travessias oceânicas e fluviais das canoas indígenas, e tornaram-se a maior referência espacial do colonialismo agrário exportador. Outro vetor ambiental alinhado nas localidades - talvez o mais determinante na escolha dos sítios - é a água potável. À parte a obviedade, há particularidades em sua ocorrência, conforme observação do arqueólogo André Prous:

Logo atrás, antecedendo a serra do Mar, há uma região baixa, ocupada por sedimentos marítimos antigos e lagoas. As consequências disso são importantes tanto para a população atual quanto para os indígenas pré-históricos. Por exemplo, a obtenção da água doce se concentra ao redor de poucos pontos; a foz dos rios é afetada pela subida da água salgada na maré alta; é necessário subir bastante o curso do rio para se obter água doce, ou esperar pela maré baixa ${ }^{19}$.

Essa disponibilidade restrita foi diretriz angular para a implantação dos núcleos investigados e, decerto, um dos fatores de suas adjacências a sopés de morros destacados na planície arenosa. Além da água doce que verte de suas encostas, essas elevações são barreiras que, nas estações frias, protegem dos ventos rigorosos provenientes do sul continental. É notável a frequência da 
implantação dos sítios no setor favorável desses abrigos naturais, levando a pensar-se no conforto térmico, e na fragilidade das construções primitivas. E, ainda, ao menos duas riquezas extrativas estão disponíveis nessas elevações confinantes: pedras (artefatos-edificações) e argila (cerâmicas-edificações).

Os nichos ecológicos compõem uma somatória de virtudes que viabilizam a sustentabilidade de suas ocupações. Dos seus contextos, também é impossível dissociar a presença de florestas no entorno. Aí, o manejo das roças de coivara, prática agrícola secular, é uma herança indígena que perdura até os dias de hoje nas comunidades caiçaras. Além da fertilidade do solo, o bioma florestal ofertava a caça, a lenha e os frutos de sua diversidade. $\bigcirc$ nicho, todavia, é uma particularização do habitat. Este, por analogia, associamos à frente atlântica da capitania vicentina, território natural onde, ao que se sabe, foram identificados os contornos da presença Tupinambá e Tupiniquim.

Segundo o sociólogo Florestan Fernandes,
20. Cf. Florestan Fernandes (1963, p. 69).

a área espacial ocupada pelo grupo local [aldeia] mantinha uma relação estratégica com o resto do território sujeito ao seu controle. A localização daquela área dentro da totalidade dos territórios dominados pelo grupo devia permitir, principalmente, acesso fácil e seguro às fontes de subsistência [...] Os dois itens evidenciam a existência de conexões gerais entre a vida na maloca e o sistema total de adaptações e controles dos Tupinambá no mundo natural circundante ${ }^{20}$.

Quanto ao delineamento espacial, fazemos ressalvas em nossa tentativa de mapear o enquadramento das ocupações primitivas (Figura 2): não

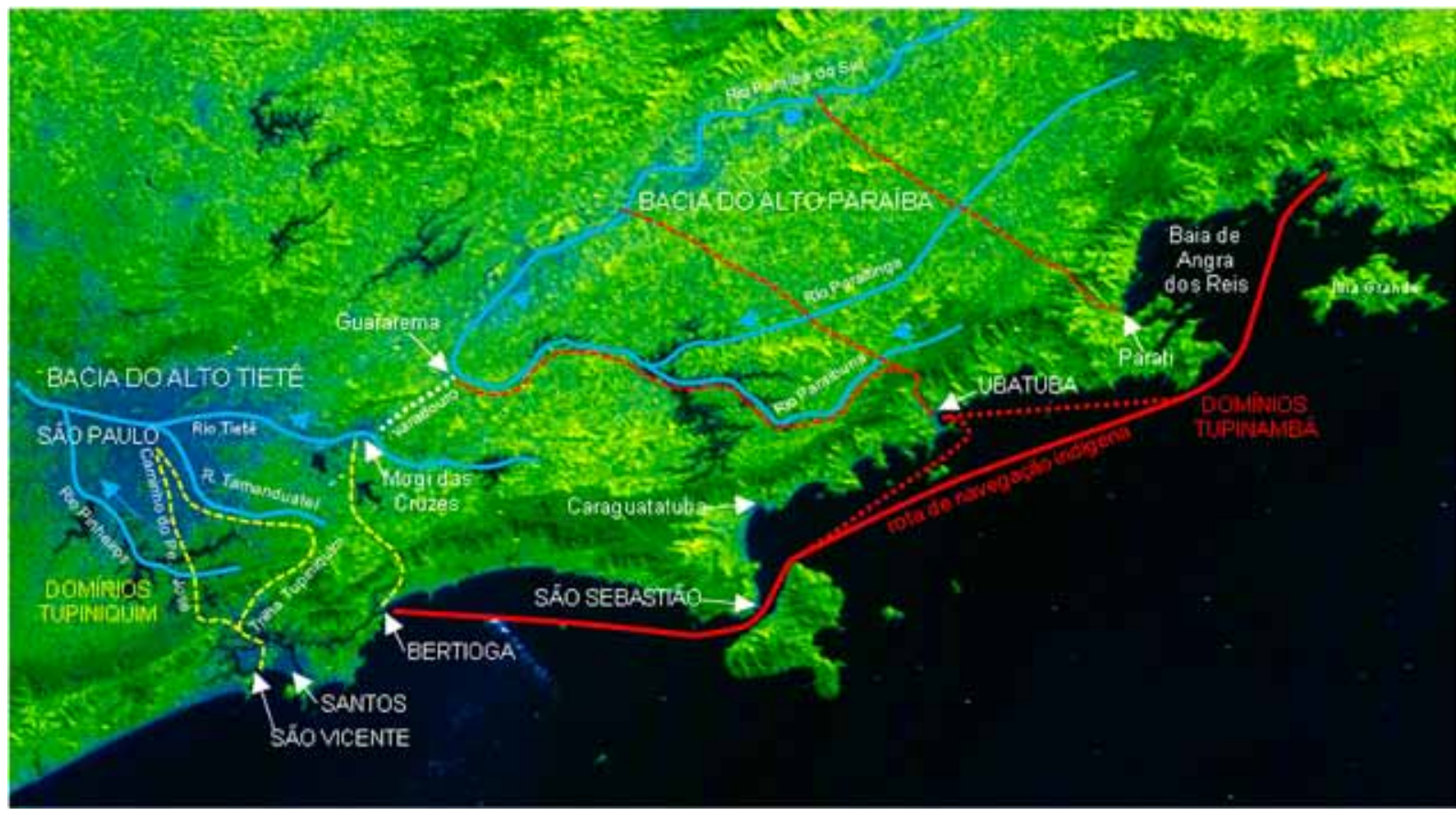

Figura 2 - Tupinambá \& Tupiniquim: interações vivenciais e ambientais nos domínios. Infográfico, elaborado pelo autor, sobre mapa obtido por satélite. Fonte do mapa: Instituto Nacional de Pesquisas Espaciais, Sat. Cbers, 2000.

Annals of Museu Paulista. v. 20. n.1. Jan.-Jun. 2012. 
21. Segundo a historiadora Beatriz Siqueira Bueno, "Território e espaço não são noções equivalentes. O território, com contornos e limites precisos,é uma categoria histórica, construída socialmente. Para além das fronteiras naturais, a fronteira política é sempre uma linha abstrata $\mathrm{e}$ convencionada por alguns"; cf. Beatriz P. Siqueira Bueno (2009, p. 251) há contornos precisos onde imperavam variantes ambientais de subsistência e dinâmicas interativas, especialmente guerreiras, entre as tribos. A noção de território ${ }^{21}$, por exemplo, com limites físicos arbitrados no campo e em suas representações, é do repertório colonizador, adventício. Conflita (até hoje!) com a percepção e o modo de vida que sociedades indígenas tinham (e têm) sobre o seu meio.

A Carta Corographica e Hydrographica de toda costa do mar da Capitania de São Paulo, uma fonte da cartografia histórica, norteou as investigações. Trata-se de um mapeamento regional, encomendado por Bernardo José de Lorena, então governador, ao engenheiro militar João da Costa Ferreira. A partir de 1789, este - com seus auxiliares Antonio Rodrigues Montesinhos (engenheiro militar), Francisco de Oliveira Barbosa, e Bento Sanches D'Orta (astrônomos) - procede a um minucioso levantamento da costa. Delineia a faixa litorânea até os contrafortes da serra do Mar, articulada com a cidade de São Paulo (Figura 3). Para os estudos, foram preciosas as Plantas Topographicas destacadas das vilas. Aqui, outra fonte cartográfica referencial são os mapas elaborados pela Comissão Geográfica e Geológica do Estado de São Paulo no início do século XX. Algumas fotos obtidas por satélite contribuem na atualização dos enquadramentos.

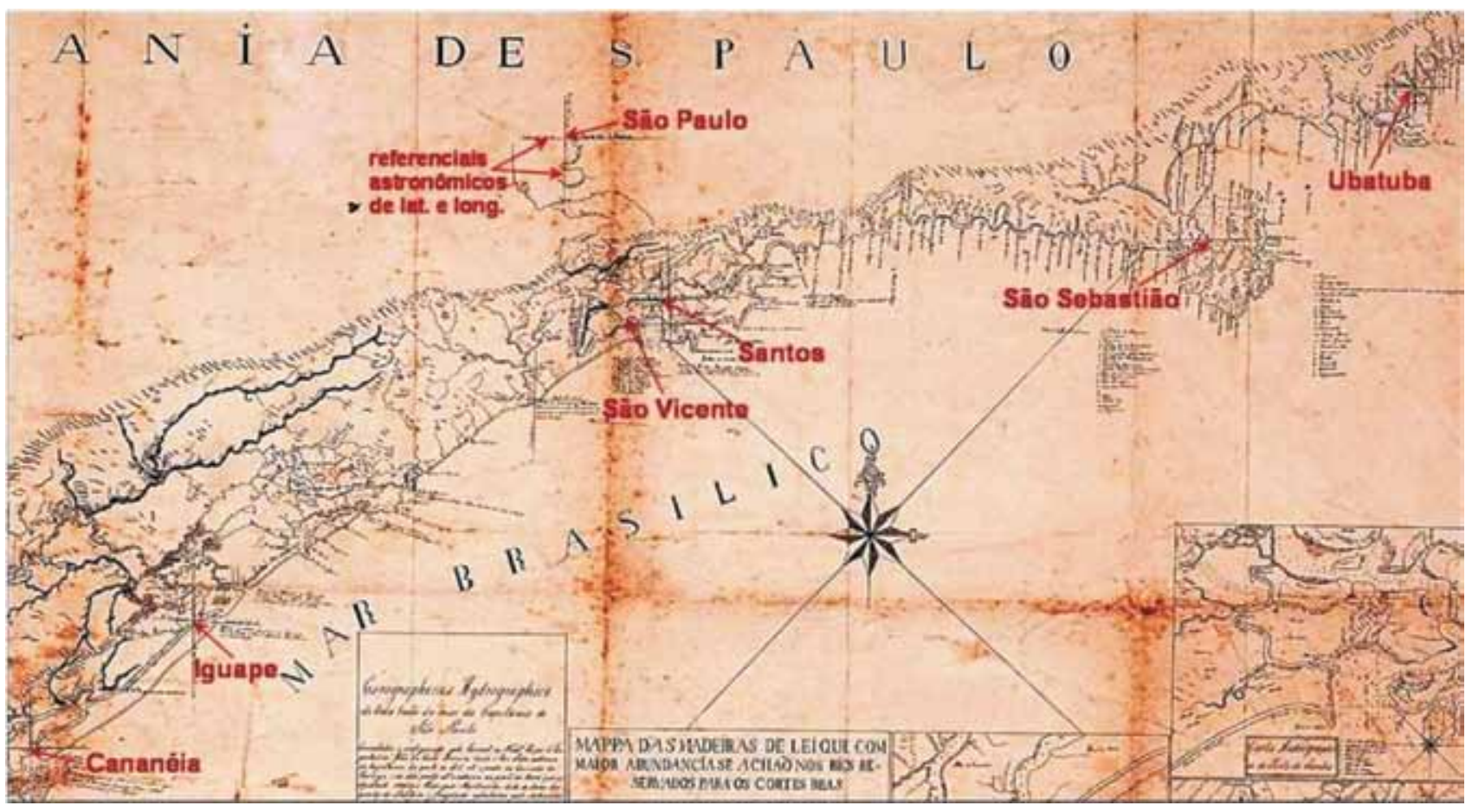

Figura 3 - A costa paulista. Infográfico, elaborado pelo autor, sobre detalhe da carta Corographica e Hydrographica de toda a costa do mar da capitania de São Paulo. Trata-se de levantamento regional pioneiro. Além dessa carta geral, as vilas aí assinaladas em cruz (referências de latitude e longitude), com exceção da vila de São Vicente, foram destacadas em Plantas Topographicas. Fonte do mapa: Museu Paulista da USP, São Paulo. 


\section{"São João Batista de Cananeia"}

Em 27 de janeiro de 1505, em sequência à navegação costeira rumo ao sul, a expedição reconhecedora da costa, de Gonçalo Coelho, tendo a bordo Américo Vespúcio, encontra abrigo na porção meridional de uma itha extensa e baixa, adjacente à costa, que terá o nome de ilha de Cananeia. Será a última localidade da costa brasileira observada por aquela esquadra, que ali ficou "fazendo aguada" até 15 de fevereiro de 1502. Provavelmente com pressuposta intenção, Gonçalo Coelho abandonou aí um dos mais enigmáticos degredados da nossa história: Cosme Fernandes, conhecido como o Bacharel de Cananeia. Estabelecido também em lguape e São Vicente, notabilizou-se nos "serviços" de apoio às navegações do Atlântico meridional, agregando, em seus redutos, outros degredados e náufragos enquanto seus "genros". Entre a criação de "galinhas de Espanha e de porcos" e a fabricação e reparo de embarcações, documenta-se também o apresamento indígena para o comercio escravagista. As localidades do litoral Sul eram especialmente estratégicas para tal atividade: articulavam-se diretamente com o Peabiru22, através das vertentes do rio Ribeira, por onde se alcançava a região dos inimigos Carijós (Guaranis). Esses adventícios interagiam culturalmente com os indígenas, da mesma forma que João Ramalho e outros portugueses conviviam com os Tupiniquim no planalto de Piratininga. Mas o nosso Bacharel, ao que tudo indica foi pioneiro. As populações nativas foram receptivas aos contatos e às permanências destes proto-colonos, "línguas da terra", em suas tribos. Foi um acolhimento delineador de seus destinos e do da capitania.

A relevância ambiental do sistema lagunar estuarino de CananeiaIguape sempre atraiu assentamentos humanos. A ilha de Cananeia, atual ilha Comprida, limita, com sua borda continental, um extenso lagamar lambiente marinho e fluvial do limite costeiro). Nas pontas nordeste e sudoeste, dois estuários de drenagem com o mar equilibram os fluxos e refluxos das marés. Suas "barras" simbolizam portais da paisagem de águas interiores, celeiro de rica diversidade ambiental. É natural que, nos remansos abrigados desses canais, os sítios secos, com disponibilidade de água doce, fossem escolhidos para assentamentos. Melhor ainda se gravitassem junto às "barras", tanto pela oferta de pescados, especialmente dos cardumes sazonais de tainha, como pela circulação marítima. Esse último componente de escolha ambiental decerto foi o que mais interessou aos ádvenas mercadores. As localidades consolidam-se como portos naturais estratégicos do alinhamento costeiro, vitais para suas atividades. Esta superposição de programas será reproduzida em todas as vilas de nossa frente atlântica.

É significativo que, nessa fase embrionária, duas povoações ocupassem locais diferentes dos sítios para onde depois foram transferidas no sequenciamento colonial. Icapara, próxima de lguape, e Maratayama, em frente a Cananeia, correspondiam à simplicidade das aldeias primitivas. Com o advento de projetos
22. "Mais recentemente arqueólogos encontraram vestígios de uma ramificação do mais famoso desses caminhos, o Peabiru dos cronistas, que ia justamente de Cananéia até o local onde fora fundada a cidade de Assunção. A via principal subia o vale do Ribeira até a nascente, cruzando depois o Paraná, onde atravessava as águas do Tibagi e do Ivaí, descendo depois o vale do Piquiri até o Paraná, saindo então do território brasileiro"; cf. André Prous (1992, p. 374). 


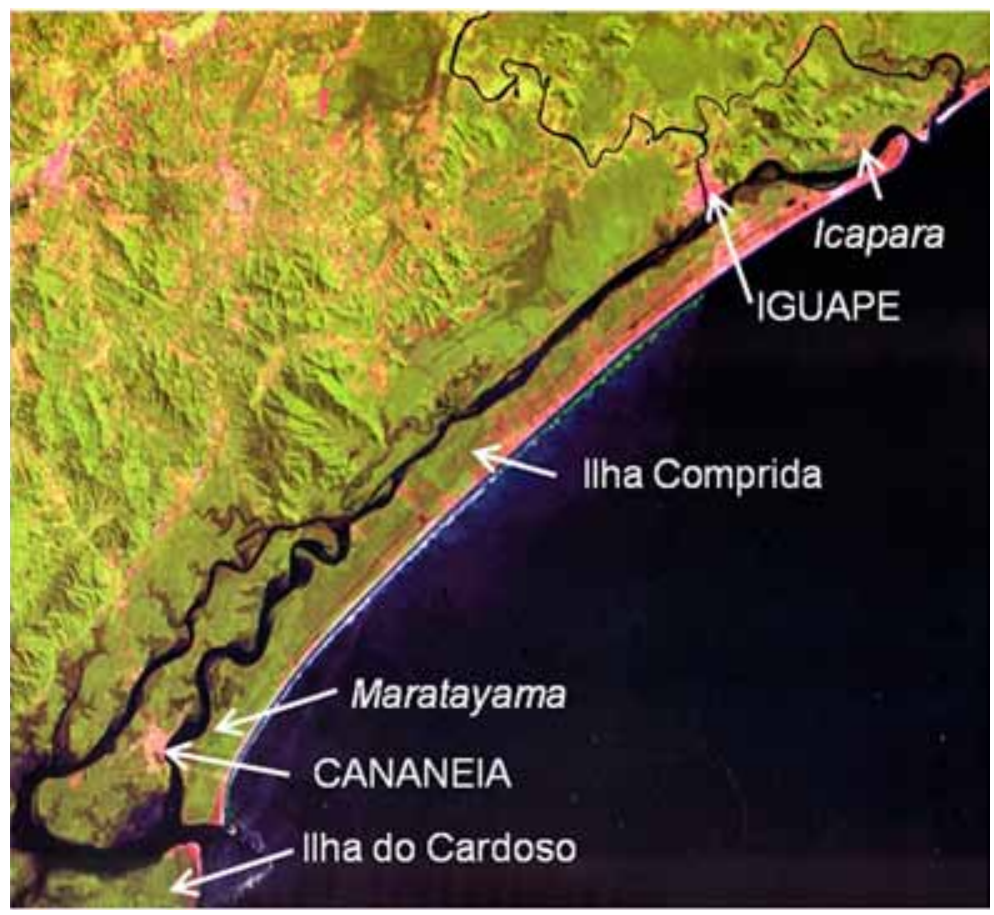

Figura 4 - $\bigcirc$ lagamar. As vilas e respectivos núcleos germinais nos estuários atrativos. Infográfico elaborado pelo autor sobre mapa de satélite. Fonte do mapa: Aziz Ab'Sáber (2005, p. 235).

coloniais mais consistentes, os colonizadores escolheram novas áreas, muito em função dos binômios praça-matriz e da projeção populacional. Observa-se que, em ambos os casos, os novos sítios escolhidos, apropriados aos novos programas, também recaíram onde existiram aldeias indígenas, conforme prospecções arqueológicas.

Os primeiros olhares descobridores focaram-se na identificação dos portos. Sem eles, não haveria comércio nem domínios. Eles vão ser os espaços vitais da Idade Moderna, portas do mercantilismo em suas diversidades. Evidentemente foram as principais referências observadas por Gonçalo Coelho, pois ele comandava uma expedição de reconhecimento, com os necessários fundeios para as "aguadas" e tomadas de altura do sol no registro das latitudes. Decerto a missão anotou aspectos gerais da costa, para a elaboração de mapas e "cartas" de navegação. Mas, muitas vezes associados aos estuários dos rios, nestas representações destacavam-se os portos, por viabilizarem as conquistas e as posses. Foi como essas localidades logo se integraram nas rotas do mundo.

A barra de Cananeia, ou barra de Itacoatiara, limita o acesso de navios de grande porte às águas interiores. Além da manobrabilidade exigida, a passagem tem pouca profundidade, atenuada nas marés altas. Porém, na porção oceânica, há outra ilha - de topônimo revelador - que supre essa carência: a itha do Bom Abrigo permite o fundeio das embarcações maiores. 


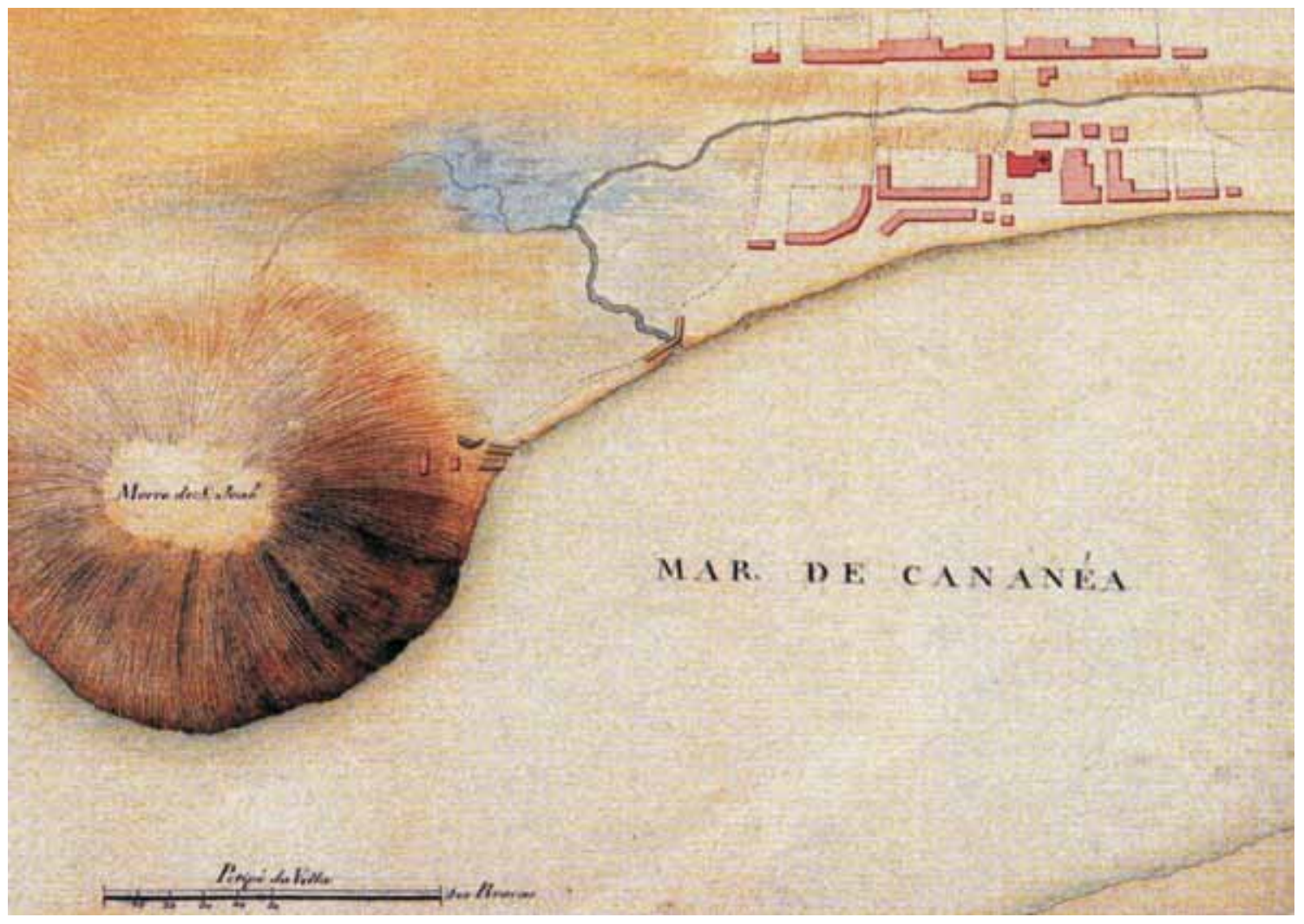

Figura 5 - João da Costa Ferreira, Villa de Cananéa, 1815. Detalhe de uma das Cartas Corographicas e Hydrographicas... Fonte: Nestor Goulart Reis Filho (200 la, p. 204).

Nessas latitudes, ela será - da mesma forma que o Porto das Naus, em São Vicente - parada obrigatória e possível para os reparos e "aguadas" das embarcações de passagem pelo continente, especialmente em direção ao cone Sul, ou a caminho das Índias. Os contatos com as instalações do continente geralmente eram feitos com embarcações menores, de apoio.

O sítio da vila ocupa um altiplano salubre, destacado em uma das ithas internas do lagamar, típicas de planície costeira. Estão presentes as fontes de água doce e o notável resguardo dos ventos de sudoeste, representado pelo morro de São João. São vetores dos nichos ecológicos identificados nas ocupações pregressas. Neste caso, o agenciamento destes fatores é determinante. Na Figura 6 , vemos que, no entorno do sítio escolhido, o relevo não apresenta outra elevação. A adjacência ao porto natural do Mar Pequeno e a próximidade do portal marítimo encerram o quadro ambiental de sua sustentabilidade.

A planta da região, fruto dos levantamentos elaborados pela Comissão Geográfica e Geológica do Estado de São Paulo, informa claramente a direção da articulação continental do núcleo urbano. É o caminho de interiorização através da planície costeira que interceptará a calha do rio Ribeira, diretriz do Peabiru. 
23. Cf. Aroldo de Azevedo (1956, p. 14).

24. Cf. Antonio Paulino de Almeida (1952, p. 12).

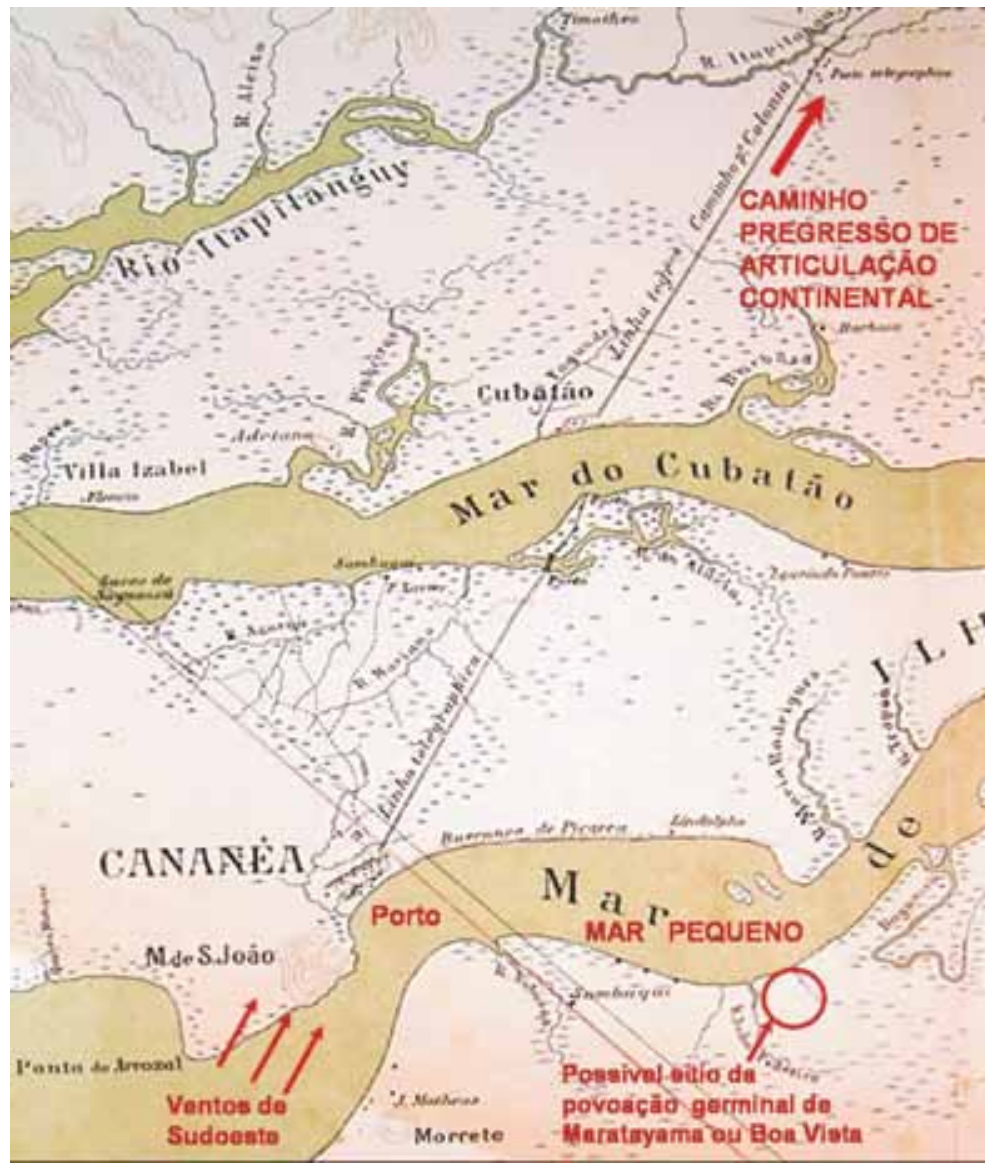

Figura 6 - Vetores. Infográfico elaborado pelo autor sobre detalhe da Planta do Litoral do estado de São Paulo entre a barra do Ararapira e Juruvaú. Fonte do mapa: Comissão Geographica e Geologica do Estado de São Paulo, 1920.

Segundo Aroldo de Azevedo, Cananeia foi elevada a vila em $1600^{23}$. No entanto, a primeira capela no local - cujas fundações foram descobertas por ocasião do restauro da Matriz atual, no espaço do altar-mor - tem seu registro no ano de 1578. Isso procede com informações, de Paulino de Almeida, de que "A primeira doação de terras na itha de Cananeia foi feita aos padres, no ano de 1601, para fazerem suas casas, mosteiro e quintais, por terem sido eles os fundadores da vila em seus princípios"24.

No desenho - o mais antigo deles - de João da Costa Ferreira (Figura 5), não foi possível identificar com precisão o vínculo entre o traçado das ruas da vila e o alinhamento do caminho continental de Cananeia. No intraurbano, sua contiguidade geralmente configura a "rua direita" do aglomerado. Nas vilas de Santos, Iguape, São Sebastião e Ubatuba, essa diretriz é uma das componentes delineadoras do desenho urbano. Podem evidenciar o sequenciamento de instalações coloniais a partir dos espaços de produção pregressa. Todavia, 


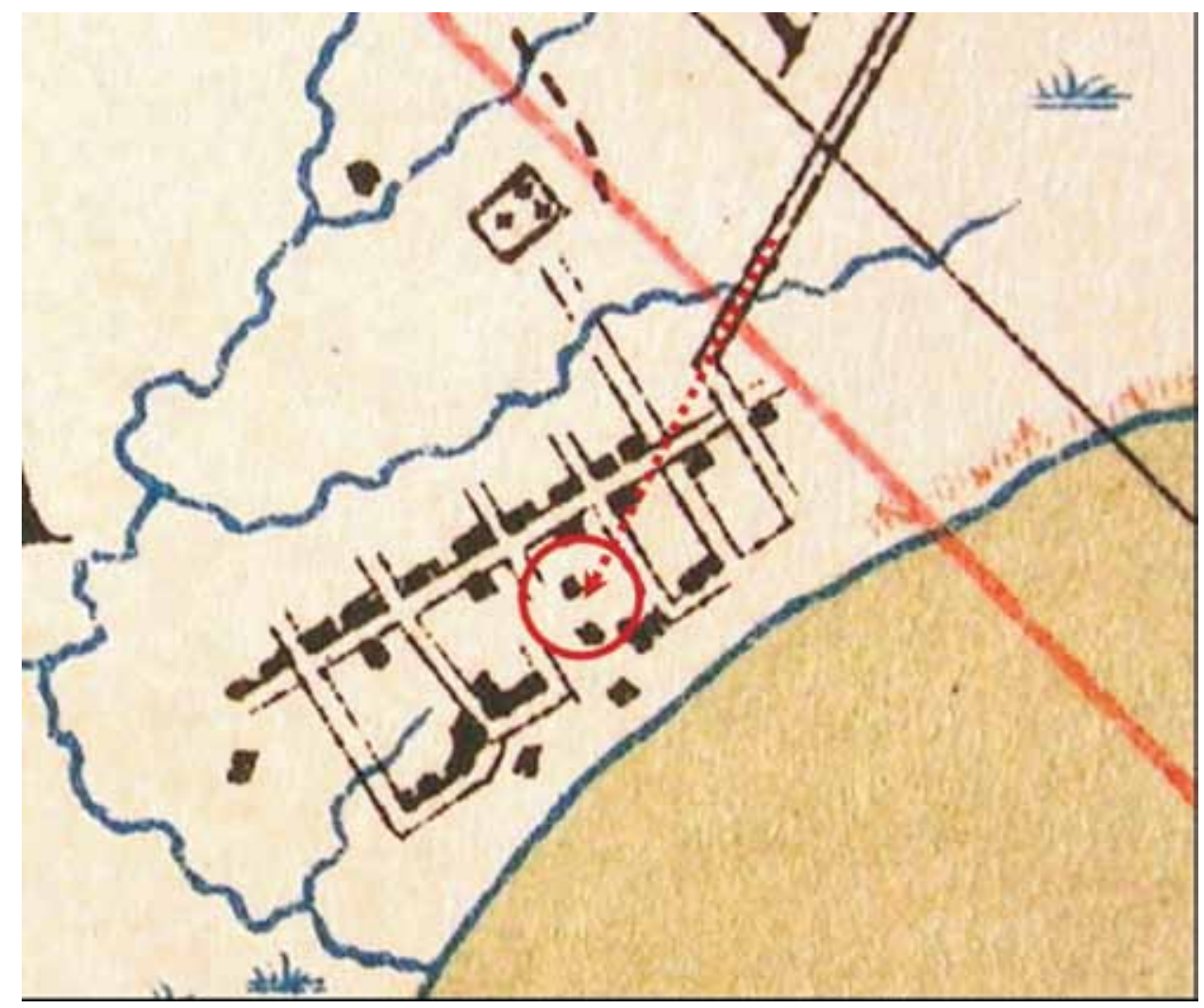

Figura 7 - Projeção do passado. Infográfico elaborado pelo autor sobre detalhe da Planta do litoral do estado de São Paulo entre a barra do Ararapira e Juruvaú. Fonte do mapa: Comissão Geographica e Geologica do Estado de São Paulo, 1920.

segundo a planta de 1920 da Comissão Geográfica e Geológica, a articulação do caminho com a malha urbana é angular, sendo significativo que a projeção do seu alinhamento alcance o embrião primitivo da povoação. Pode ter havido uma adequação evolutiva. Pensamos que, nesse caso, a geometria do módulo urbanístico primário, o binômio Praça-Matriz, somada aos alinhamentos da costa e do córrego adjacente, prevaleceu na expansão do tecido diante da diretriz continental primitiva.

\section{"Villa de Nossa Senhora das Neves de Iguape"}

Iguape situa-se na porção continental do lagamar, nas proximidades do "portal" norte da itha Comprida conhecido como barra de Icapara. Nas adjacências encontra-se também o estuário do rio Ribeira de lguape (Figura 8). Os caudais desse rio são expressivos: drenam a maior planície costeira da frente atlântica do estado de São Paulo. Ao contrário do que ocorre no Litoral Norte, a serra do Mar, a partir da baixada vicentina, afasta-se progressivamente dos limites marinhos na direção sudoeste, permitindo planícies de maior amplitude até 


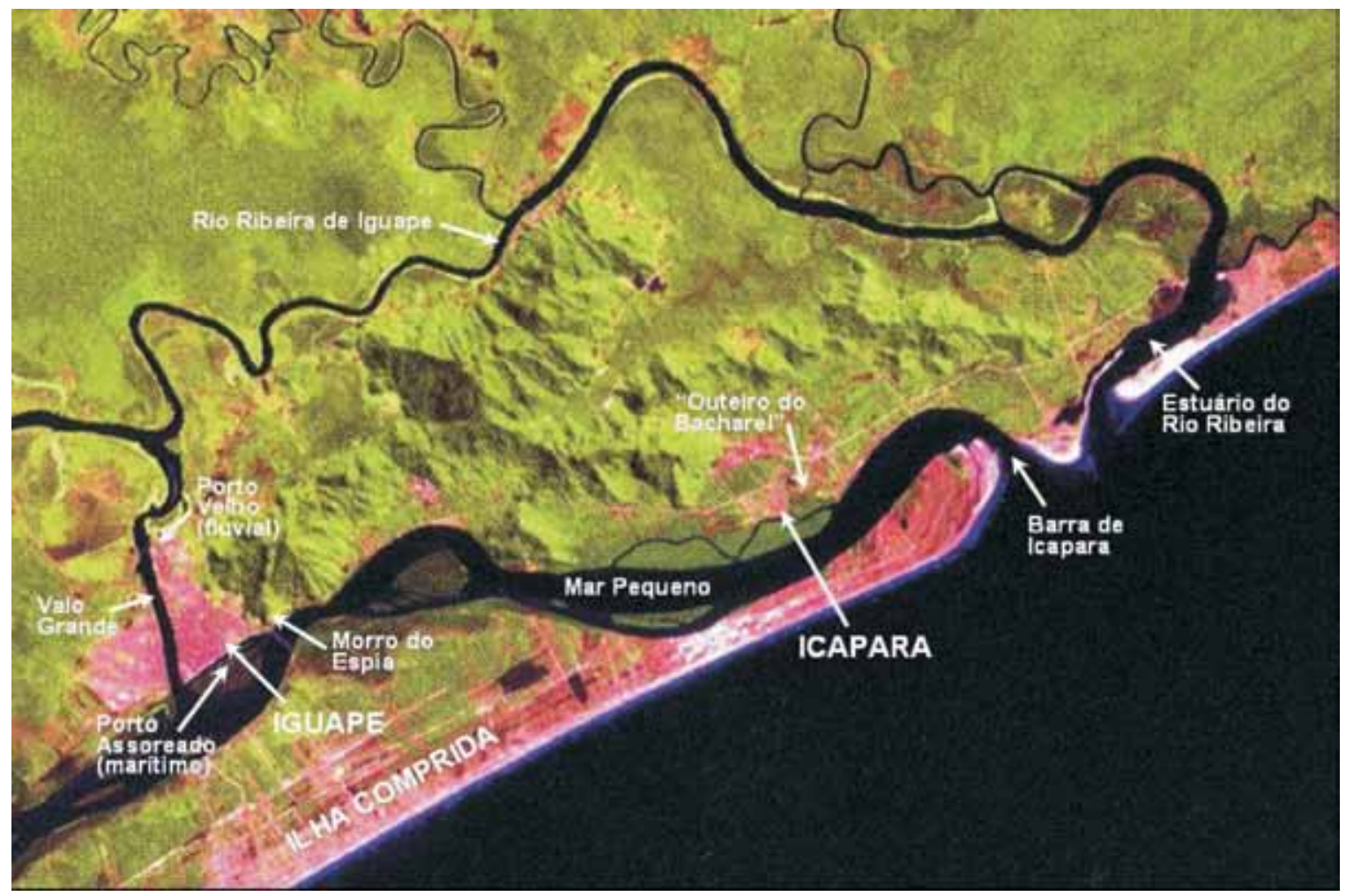

Figura 8. A interação das águas. Infográfico elaborado pelo autor sobre mapa de satélite. Fonte do mapa: Aziz Ab'Sáber (2005, p. 235).

25. Cf. Ernesto G. Young (1902, p. 225). configurar a bacia hidrográfica do Ribeira. Ao sul desse amplo "anfiteatro", no entorno de Cananeia, a serra novamente debruça seus contrafortes no mar e prossegue em direção ao sul. Assim, a paisagem geográfica dessa região, contida pelo relevo serrano, parece representar o relativo isolamento regional que perdura até hoje perante o conjunto de atividades sociais do estado de São Paulo.

O sítio do núcleo urbano insere-se na paisagem das águas. Estratégico, interpõe-se entre a porção norte do sistema lagunar estuarino e o baixo Ribeira. A percepção da vitalidade ambiental decerto remonta à nossa pré-história. Os remotos sambaquis e os grupos locais de subtradição Tupi evidenciados reiteram sua exuberância. $\bigcirc$ sequenciamento europeu, portanto, é um desdobramento previsível.

O nosso Bacharel, interagindo com a sociedade Tupi, também se estabelece em lcapara. $\bigcirc$ historiador Ernesto Young afirma: "a primeira povoação e villa de lguape de que temos provas incontestáveis, existia ao pé de um pequeno monte chamado 'Outeiro do Bacharel'"25. A seguir informa que o outeiro localizase em frente à barra de lcapara, pelo lado de dentro, e que hoje é conhecido pelo nome de "Morro do Icapara". Adiante reitera: "é provado que existia uma povoação ao pé do 'Outeiro do Bacharel' anteriormente ao anno de 1577, anno 
este em que [foi] aberto um Livro do Tombo da Egreja dedicada a Nossa Senhora das Neves" 26 .

A mudança da "vila velha" de lguape para o sítio atual vai ocorrer no século seguinte. "É geralmente citado o anno de 1654 como sendo aquele em que foi elevada [a vila]"27. $\bigcirc$ autor, no entanto, enumera diversos documentos que indicariam sua elevação em época anterior, antes mesmo da mudança, "e que esta mudança foi effectuada durante os anos imediatamente anteriores a 1637 , em cuja data ficou concluída a lgreja Matriz"28. Adiante, Young escreve: "Os terrenos, por ocasião da mudança da Villa, pertenciam a Francisco Alves Marinho, descendente de Cosme Fernandes [o Bacharel] e Francisco de Chaves"29.

Com o mesmo perfil de Cananeia, as novas instalações de lguape, atendendo aos novos programas do colonialismo, ocupam sítio plano de planície costeira, adjacente às águas, ligeiramente elevado em relação ao entorno, com área suficiente na escala de implantação dos seus contextos sociais. Não perdem os atrativos ambientais que os viabilizam. Não por acaso, recaem em área de escolha pregressa indígena ${ }^{30}$.

A "rua direita" é claramente identificada. Assim se chamava até mudar para a denominação atual - rua 9 de Julho -, mantida até hoje. Perpendicular à praça, sua diretriz polariza significativamente o Porto Velho (Figura 8). Este portal fluvial articulava a localidade com as amplitudes da bacia hidrográfica. A
26. Idem, p. 226.

27. Idem, p. 236

28. Idem, p. 238

29. Idem, p. 241; grifo nosso.

30. Segundo Maria Cristina Scatamacchia,"É quase certo que a própria cidade de Iguape esteja situada sobre uma antiga aldeia indígena, pois em várias ruas do perímetro urbano foram identificados vestígios cerâmicos, tendo a Sabesp, há uns cinco anos [...], executando trabalhos de saneamento, encontrado uma urna no largo da matriz."; cf. Maria Cristina Mineiro Scatamacchia (1990, p 203). Sobre Cananéia, informação pessoal da arqueóloga relata, também, o encontro de uma urna funerária na área do porto da cidade.

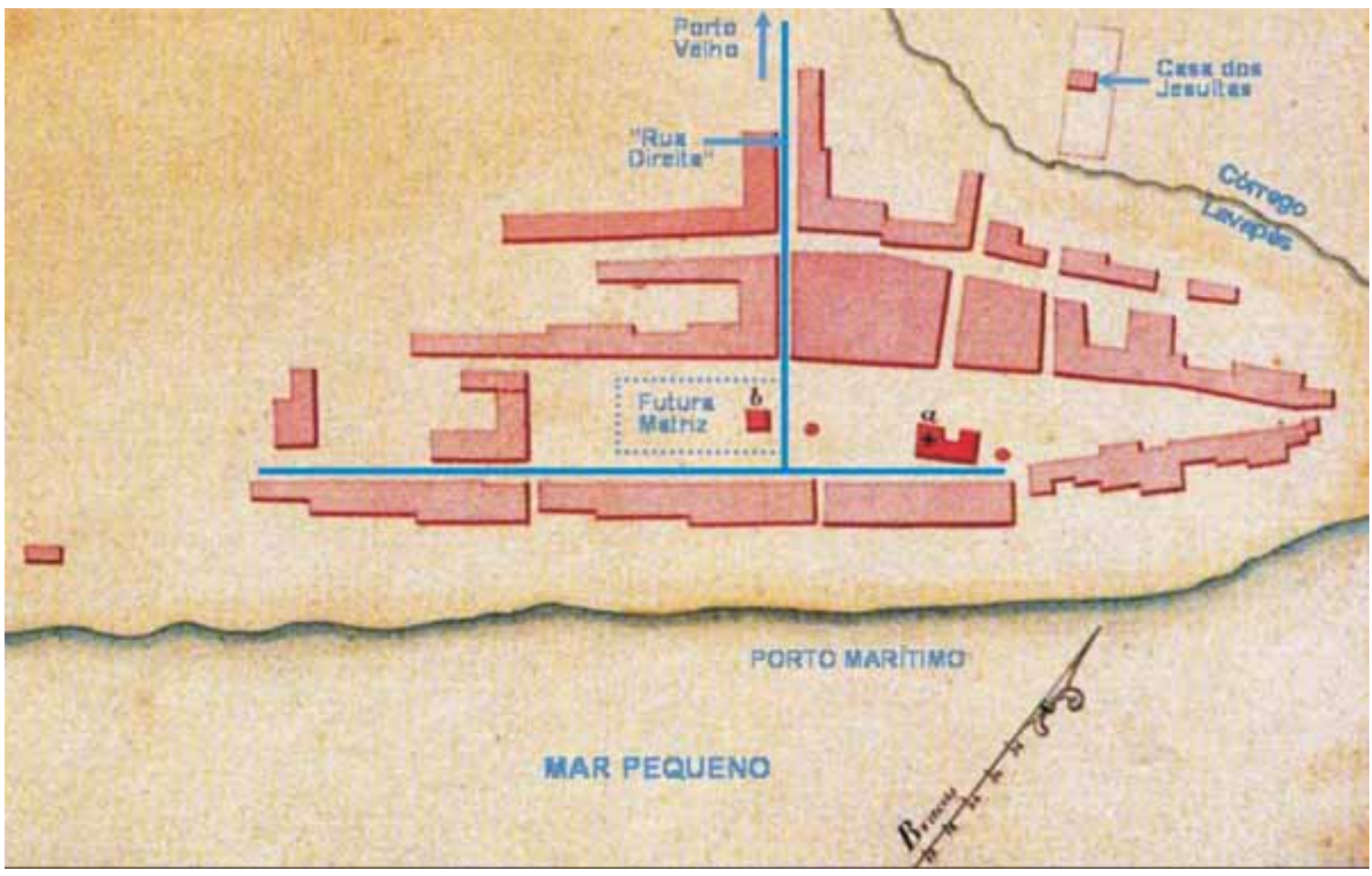

Figura 9 - Vetores urbanos. Infográfico elaborado pelo autor sobre detalhe de uma das Cartas Corographicas e Hydrographicas..., de João da Costa Ferreira, 1815. Fonte do mapa: Nestor Goulart Reis Filho (2001a, p. 203). 
31. Cf. Washington Luís (1980, p. 66). estratégia do sítio surpreende. Permeia o universo continental e os horizontes marinhos. E responde, no nível tecnológico dos meios de transporte, para as circulações do habitat. Para canoas a remo, a partir da posição do Porto Velho, não é tarefa fácil continuar pelo rio Ribeira, romper seu estuário, geralmente em condições adversas, navegar um trecho de mar aberto, romper novamente a barra de Icapara, outro duelo, para enfim alcançar o sítio de lcapara ou de lguape. As vivências interativas do habitat, pregressas e coloniais, delinearam naturalmente este vetor de ocupação por terra. A objetividade da rua Direita de lguape retrata isso. A demanda pela ligação foi progressiva no colonialismo.

No início do século XIX, a região consolida-se como produtora e exportadora de arroz. A elite local promove a abertura do Valo Grande. O que se pretendia benéfico ao transporte fluvial da produção, evitando-se o transbordo por terra até o porto marítimo, foi a causa do seu colapso: o efeito imprevisível da intervenção do homem no complexo e equilibrado sistema hidrológico natural alterou o seu destino. $O$ estreito canal entre o rio Ribeira e o Mar Pequeno, aberto por escravos, cujas obras atravessaram dois Impérios, cedeu suas margens de solo arenoso à fúria das águas do rio, que encontraram caminho mais curto para o desnível natural da marinha. A dragagem progressiva das margens assoreou em poucos anos o porto marítimo natural da vila, inviabilizando-o para sempre. Iguape já experimentara, no século XVII, outra vivência cíclica efêmera: a do ouro. Algumas minas nos contrafortes serranos do fundo do vale esgotaram-se rapidamente, deixando na cidade a primeira casa de fundição da colônia (1630), hoje Museu Municipal.

\section{São Vicente \& Santos}

\section{"Sam Vicente"}

No Atlas de Kurstman (1502-1504), já se encontram os nomes "Rio S. Vicente" e "Porto S. Vicente" devidamente assinalados ${ }^{31}$. Não há documentação que comprove ter sido São Vicente feitoria régia, como o foram, ao menos, as de Cabo Frio e Igaraçu. Outras duas (Rio de Janeiro e baía de Todos os Santos), também são nebulosas quanto à comprovação de terem sido iniciativas da corte. Mas é inegável a presença de europeus na baixada vicentina nas primeiras décadas quinhentistas. De passagem pelo local, duas expedições espanholas uma em 1528, com destino ao rio da Prata, e outra em 1530, de lá retornando - deixam preciosos relatos das atividades e feições de uma povoação local. Da primeira, comandada por Diego Garcia, as informações são as seguintes:

E de aqui fuimos a tomar refresco en S. Vicente questa en 24 grados, e alli vive un Bachiller e unos yernos suyos mucho tiempo ha que ha bien 30 años, é alli estuvimos hasta 15 de Enero del año seguiente de 27 é aqui tomamos mucho refresco de carne e pescado e de las vituallas de la tierra para provision de nuestra nave é água é lena é todo lo que ovimos menester, é compre de un yerno deste Bachiller un vargantin que mucho servicio nos hizo; e mas 
el próprio se acordó con nosotros de ir por lengua al rio [da Prata], y este Bachiller con sus yernos y hicieron comigo una carta de fletamiento para las truxese en Espana con la nao grande ochocientos esclavos, é yo la hice con acuerdo de todos mis officiales é contadores é tesoreros (...) y esta uma gente alli con el Bachiller que comen carne umana y es mui buena gente amigos de los cristianos que se llaman Topies ${ }^{32}$.

Na outra expedição, sob o comando de Sebastião Caboto, encontravase o cosmógrafo Alonso de Santa Cruz, que descreve:

Dentro do porto de S. Vicente há duas ilhas grandes, habitadas por índios e, na mais oriental [de Santo Amaro], na parte ocidental, estivemos mais de mez. Na ilha ocidental têm os portugueses um povoado chamado "S. Vicente" de dez ou doze casas, uma feita de pedra com seus telhados, e uma torre para defesa contra os índios em tempo de necessidade. Estão providos de coisas da terra, de galinhas de Espanha e de porcos, com muita abundância de hortaliça. Têm essas ithas uma ilhota entre ambas de que se servem para criar porcos [provavelmente a atual itha de Barnabé]. Há grandes pescarias de bons pescados ${ }^{33}$.

Eram os domínios litorâneos do Bacharel, até a esquadra de Martim Afonso de Souza aportar aí, em 22 de janeiro de 1532, no aniversário de São Vicente (exatamente trinta anos após a passagem de Gonçalo Coelho e Américo Vespúcio).

A expedição afonsina, mesmo não sendo parte de um plano reinol de colonização (como muitas vezes a consideraram), deixa desdobramentos importantes e comprometedores para o sequenciamento das instalações portuguesas, razão direta da presença dos viajantes que aqui permaneceram. Serão novos tempos para São Vicente. Fala-se em 150 homens. Pelo evidente perfil exploratório das "terras a achar e descobrir" - minas de ouro e prata -, não havia mulheres na esquadra. A longa permanência dessas pessoas (16 meses até o retorno de Martim Afonso ao reino) deve ter contribuído para alguns tripulantes optarem por se instalar no local por mais tempo. A expectativa de descobertas nos horizontes de tantos sertões, além das lendárias terras peruanas, coadunavase com os espíritos aventureiros. Com atribuições pertinentes, Martim Afonso doou sesmarias no litoral e no planalto contíguo, diretriz das ocupações rurais que foram se estabelecendo; não há registros, mas o povoado do Bacharel, pré-existente, provavelmente acolheu novas habitações, ainda precárias ou de melhor padrão, consolidando o mesmo sítio. Hoje entendemos que foi um período de transição ainda descomprometido com o futuro projeto colonial agrário exportador. Justificase a permanência na povoação já existente pelos critérios de escolha dos habitantes antigos; foram suficientes, aos novos colonos, as mesmas condições ambientais protetivas ali encontradas: água doce, abrigo dos ventos do sul, defesa de ataques corsários pela baixa profundidade de sua enseada e, ainda, essa parte ocidental da itha era oposta ao setor de penetração das investidas Tupinambá, vindas da frente oriental. Por ali foram se instalando, ao que tudo indica, seguindo a disposição preexistente.
32. Cf. Mário Neme (1959, p. 23).

33. Cf. Washington Luís (1980, p. 66). 
34. Cf. Mário Neme (1959, p. 86).
No planalto, Martim Afonso nomeia João Ramalho "guarda-mor da borda do campo"; juntamente com Antonio Rodrigues, ambos são citados - no registro da sesmaria que concede a seu lugar-tenente Pero de Góis - como "línguas da terra, e nela estantes de 15 a 20 anos". Outra sesmaria é concedida ao fidalgo Rui Pinto, ambas em outubro de 1532. Os colonos que ocuparam o planalto dispersaram-se pelo entorno dos campos de Piratininga, interagindo culturalmente com os Tupiniquim.

Neste período, poucos anos após o retorno de Martim Afonso, a região vicentina vivenciará seu primeiro projeto colonial. Com a divisão do Brasil em Capitanias Hereditárias, D. João III escolhe, através de duas Cartas, o leal amigo que ali esteve para ser donatário dessa frente atlântica; Pero Lopes de Souza também recebe uma faixa territorial, menor que a do irmão, confusamente arbitrada em permeio à dele. Isto ocorre entre fins de 1534 e início de 1535. Antes dessas nomeações, Martim Afonso já estava em Goa, na Índia, onde fará carreira promissora até ser Vice-rei da Índia. Mas deixa procuração à sua esposa para as providências necessárias: Dona Ana Pimentel será signatária das decisões relativas aos domínios vicentinos. Gonçalo Monteiro é o primeiro capitão-mor da capitania, nomeado por ela. Decerto será ele o responsável pela ereção da vila de São Vicente. A partir de agosto de 1537, documentos confiáveis mencionam São Vicente como vila. Não há registro de seu foral; supõe-se que, sob as ordens de Monteiro, tenha sido elevada entre 1536 e 1537, onde já se encontrava ${ }^{34}$.

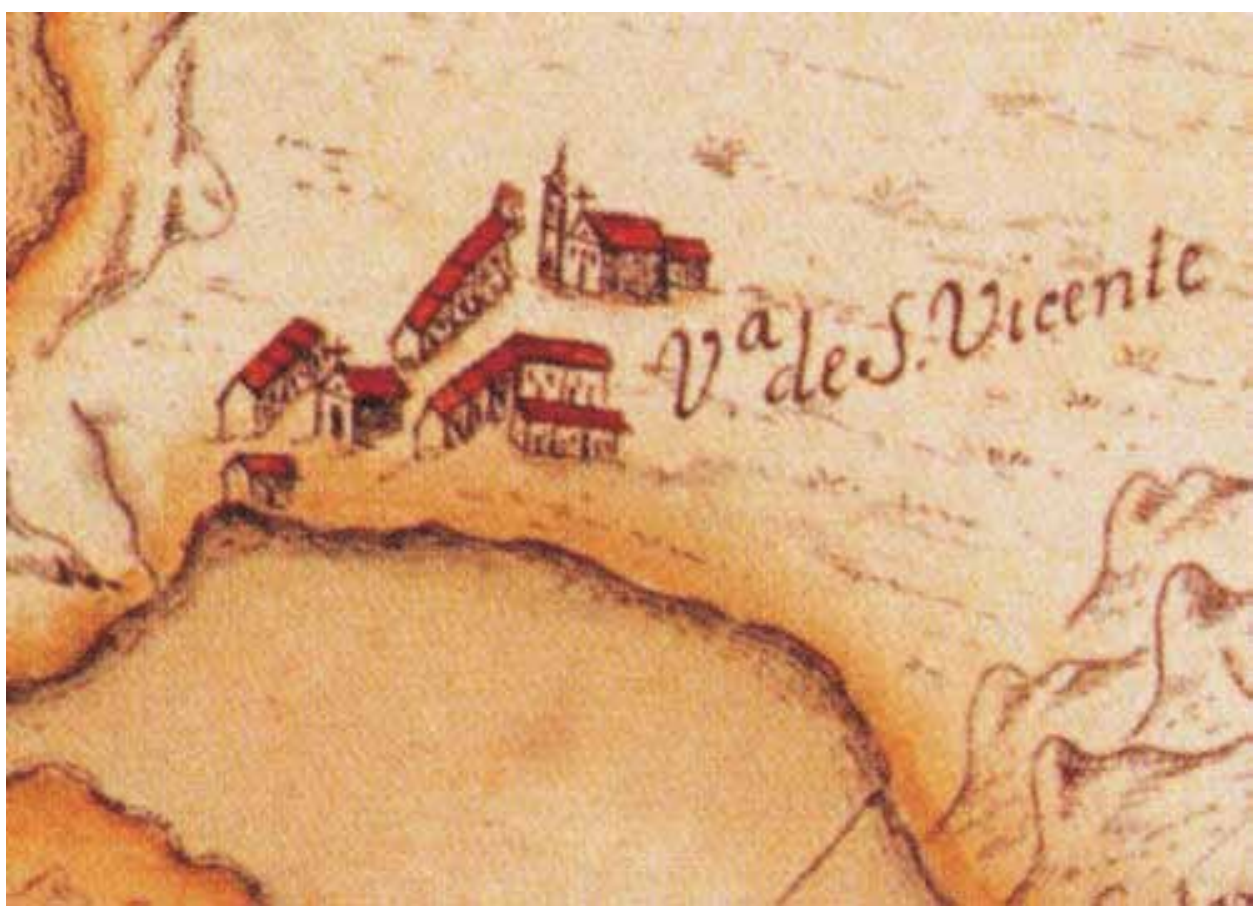

Figura 10 - A persistência do sítio. Detalhe de Planta da barra da Villa de Santos, de autor desconhecido, ca. 1765-1775. Fonte: Nestor Goulart Reis Filho (200 la, p. 199). 
Enquanto sede da capitania, o novo status de vila para o povoado de São Vicente representará mais uma etapa de consolidação do seu núcleo germinal; embora sem registro, com certeza foram acrescentadas novas instalações para atender às exigências formais e ao novo contingente de colonos - ao que tudo indica, nada que fosse de arquitetura significativa, e não restaram ruínas. É que, em 1542, uma enorme ressaca ou maremoto (de qualquer forma um incidente natural sem precedentes) destruiu suas edificações; foi reconstruída no sítio do atual centro histórico; talvez estivesse mais próxima da praia, em cota inferior, não sabemos, mas, ao que tudo indica, estava nos terrenos do entorno. Não foi seu primeiro revés. Em 1534, sofre violento ataque liderado pelo intrépido tenente espanhol Ruy Garcia Moschera, que a saqueia e incendeia, ocasionando a morte de vários colonos deixados por Martim Afonso, "cerca de 100 pereceram no confronto". Foi o episódio conhecido com a Guerra de lguape. Reerguida pelos sobreviventes, retoma seu destino até o passo maior da criação da vila poucos anos depois. Portanto, duas adversidades arrasaram sua representação espacial em menos de dez anos. As vantagens das condições ambientais do sítio resistiram; se não foram questionadas nas duas reconstruções, é porque atendiam às necessidades vivenciais dos habitantes.

Mas seu destino parecia de qualquer forma comprometido. Em resposta ao projeto colonial agrário-exportador, a incipiente produção açucareira da baixada vicentina demandava articulação eficaz com instalações portuárias. Os novos programas sociais colocaram em cheque as vantagens ambientais do sítio primitivo.

Mesmo revitalizada pelo novo status jurisdicional, a vila de São Vicente estava dissociada daquilo que passou a ser a referência espacial predominante do projeto colonial: um porto mais adequado. Este, por seu significado econômico, será a base para a gênese de Santos. Em relação a este novo núcleo, não fossem os forais independentes, São Vicente poderia enquadrar-se na designação comum de "vila velha". A manutenção das duas vilas será questionada, anos depois, pelo próprio governador-geral Tomé de Souza.

O nicho ecológico da primeira vila corresponde perfeitamente aos sítios de ocupação Tupi. Sabemos que a baixada vicentina era ocupada sazonalmente pelos Tupiniquim que habitavam Piratininga. Desciam pelos caminhos de ligação com o planalto (período dos contatos, a articulação utilizada era a trilha Tupiniquim). É natural que escolhessem as barras do lagamar vicentino para seus acampamentos, onde a concentração dos cardumes de tainha facilitava seu apresamento. O sítio de São Vicente estava perfeitamente adequado.

Protegido pelo "morro dos Barbosas" dos ventos do setor sul, implacáveis nessa época do ano, de sua encosta também vertia a água doce necessária. Conjugava essas variáveis ao remanso portuário do Tumiaru; este não era tão favorável como o de Santos por causa da pouca profundidade, mas atendia adequadamente a logística das embarcações menores, especialmente canoas, tão significativas no contexto de circulação do estuário. Um fator sobrepunha sua vantagem em relação ao sítio de Santos: sua localidade era mais 
35. É significativo o malogro da vila de Santo André, fundada em 1553, por iniciativa do governador Tomé de Souza para resgatar o controle e a "reconversão" dos colonos dispersos no planalto, conviventes com os Tupiniquim.A escolha do local, na diretriz da trilha Tupiniquim, porém isolado das aldeias indígenas (talvez por afirmação de poder), teve vida curta: $o$ procurador da Câmara, em vereança de 20 de setembro de 1557 , propõe: "como estavam em esta dita vila e morriam de fome e passavam muito mal e morriam o gado [...] que se fossem dentro do termo dela de longo dalgum rio"; cf. Mário Neme (1959, p. 178).

36. Cf. Washington Luís (1980, p. 78).

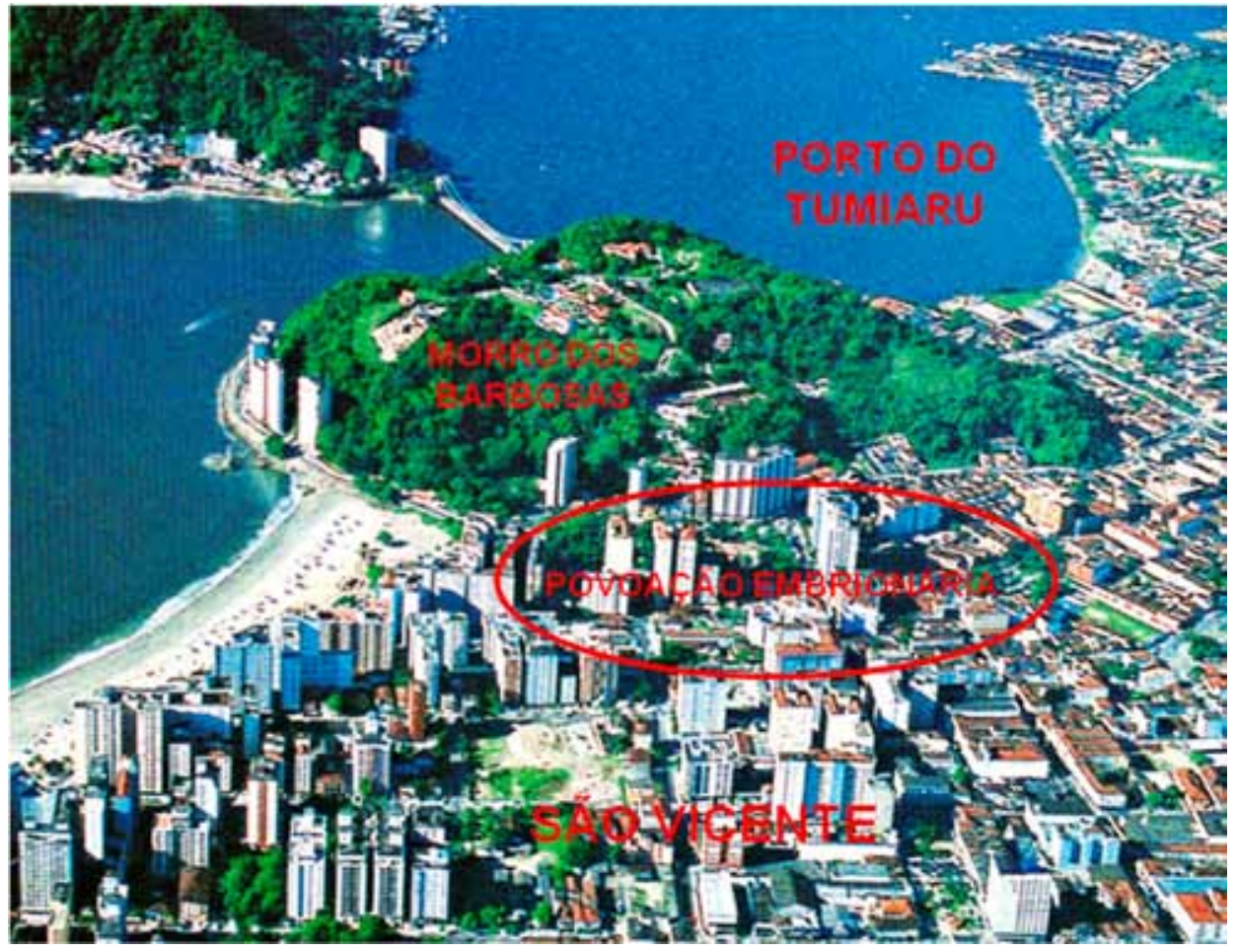

Figura 11 - O sítio apropriado. Infográfico elaborado pelo autor sobre vista aérea de São Vicente. Fonte da imagem: Aziz Ab'Sáber (2005, p. 223).

defensível em relação aos assédios dos Tupinambá que adentravam, principalmente pelo canal de Bertioga, na direção nordeste.

É notável que duas destruições em menos de dez anos e a fundação de Santos não tenham bastado para seus povoadores desistirem. Foi o que ocorreu com a inadequada Santo André, quando desdenhou os indicativos das ocupações pregressas ${ }^{35}$. Simbolicamente, as instalações edilícias de São Vicente talvez não tivessem a mesma importância que suas atribuições ambientais. Prevaleceu, portanto, o abrigo acolhedor, gradativamente sequenciado até os dias de hoje.

\section{"Villa de Santos"}

A natureza selou o destino da cidade portuária. Para seu futuro, Santos reserva intensa atividade - de portal do colonialismo agrário exportador da região vicentina ao mais significativo terminal mercantil do país. Confirmou-se o prognóstico de Tomé de Souza, primeiro governador-geral. Em carta ao rei D. João III, de 1 de junho de 1553, relata: "a [vila] de Santos [...] tem o melhor porto que se pode ver, e todas as naus do mundo poderão estar nele com os proizes [amarras] dentro em terra"36. Seu entusiasmo não ocultou sua surpresa. A escolha apropriada do local para o binômio porto-povoamento de Santos não foi 
deliberação da corte. Foi o máximo do esforço de alguns colonos, dispostos a viabilizar os propósitos mercantilistas de sua presença na região, premidos pela necessidade de um escoadouro adequado para a incipiente produção dos primeiros engenhos de açúcar da colônia. O local, diametralmente oposto ao sítio da vila de São Vicente, na mesma ilha, suplantava as condições portuárias inadequadas desse primeiro núcleo urbano.

O território da itha de São Vicente foi gradativamente ocupado por instalações rurais. Tem-se notícia de que os pioneiros foram dois engenhos de açúcar: o dos irmãos Góis, em 1533; e o dos irmãos Adorno, em 1534. O principal, "engenho do Governador" ou dos Erasmos, é do inicio da década seguinte. Essas instalações gradativas encontraram no interior da ilha os terrenos mais secos apropriados aos cultivos. Demandaram articulação de caminhos, da sede da vila às margens do canal de navegação a nordeste. Ali estavam as terras do "Enguaguaçu", onde "Nos primeiros anos, quando todos os povoadores lavraram nesta llha, onde queriam, Pascoal Fernandes Genovês e Domingos Pires fizeram sociedade, e ambos vieram situar-se em Enguaguaçu" ${ }^{\prime 37}$. Frei Gaspar da Madre de Deus informa também que: "Para sua particular serventia abriram os ditos sócios o caminho antigo de Santos para S. Vicente, o qual principiava na sua casa, continuava por uma ladeirinha, e passava por detrás do outeiro, onde hoje está o Mosteiro de S. Bento"38. Talvez seja a primeira via de iniciativa colonizadora de que se tem registro.
37. Cf. Frei Gaspar da Madre de Deus (1975, p. 111).

38. Idem, ibidem.

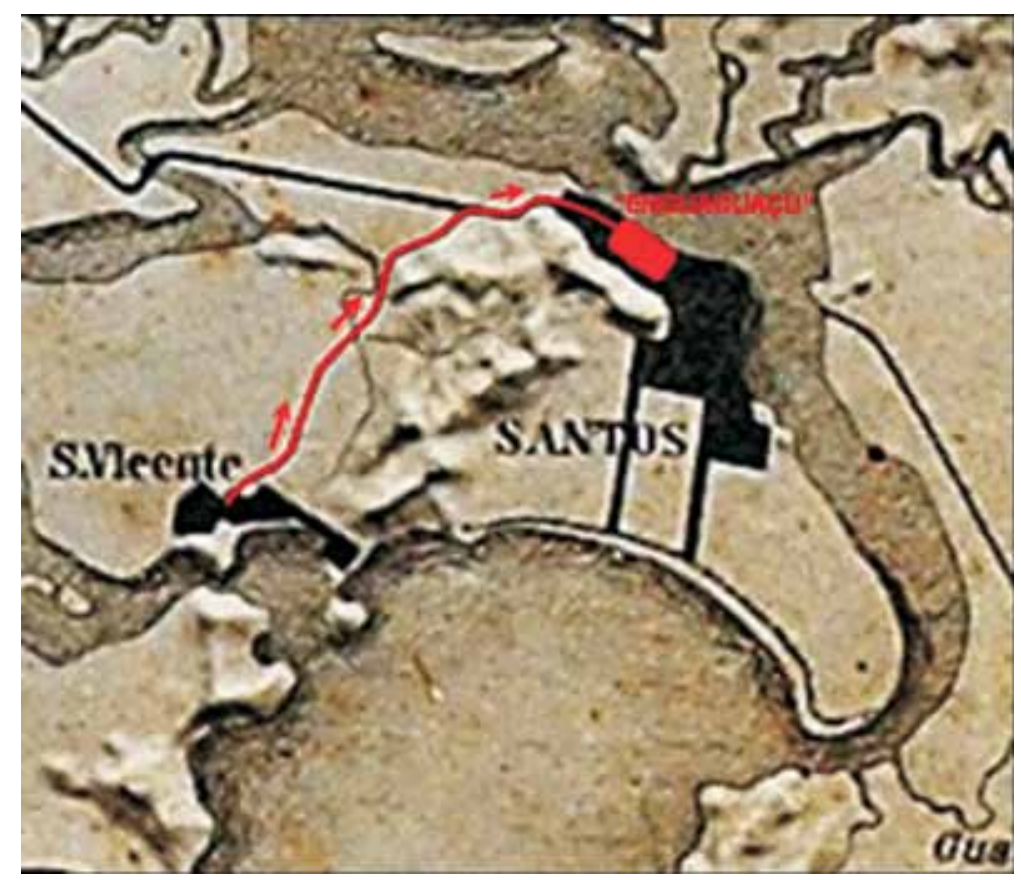

Figura 12 - $\bigcirc$ sítio ideal. A esplanada do binômio porto-povoação entre os morros e o canal portuário, alcançada pelo caminho. Infográfico elaborado pelo autor sobre detalhe de maquete - São Paulo and Santos - do relevo. Fonte da maquete: Museu Paulista da USP. 
39. Cf. Pasquale Petrone (1965, p. 45).

40. "Como imagem de síntese, a 'Rua Direita' que corresponde ao arquétipo tido como original do urbanismo português, era a rua onde se encontravam os estabelecimentos dos comerciantes mais importantes [...] Nas cidades marítimas ou fluviais, a 'Rua Direita' surgiu fundamentalmente em duas situações: ligando o principal acesso terrestre ao cais ou como via paralela à margem"; cf.Walter Rossa (1995, p. 251).
Dessa forma, em meados da década de trinta, chegaram ao sítio ideal que, em 1553, tanto agradará aos olhos do governador. Mas antes disso encantou também a outros olhares. $O$ polêmico Brás Cubas, colono articulado com as gestões do reino e da igreja, "adquiriu parte das terras dos proprietários do Enguaguaçu, ainda desocupadas, e que abrangiam o outerinho de Santa Catarina [onde ...] iria definir-se o povoado de Santos. Aí Brás Cubas teria erguido o primeiro monjolo que se conheceu no Brasil, assim como o primeiro Hospital de Misericórdia do país" 39 .

Houve, decerto, uma convergência de vetores positivos para o sucesso do novo núcleo, elevado a vila em 1545. A condição portuária sem dúvida promove o empreendimento - profundidade adequada, facilidade de atracação em terrenos secos, e abrigo natural de ventos e correntes marítimas. Na verdade, tal adequação estende-se ao longo de grande parte do "rio de S. Vicente", atual Canal de Santos, o que permitiria outra pontuação germinal. Nesse alinhamento, porém, um vetor de amplitude ambiental contribuiu para o local escolhido: a sua geomorfologia. Em sua porção central, intercalam-se alguns maciços elevados que, diferenciando o relevo, alcançam o setor nordeste da itha, num alinhamento de morros paralelos à margem do canal, com o Monte Serrat, sobrelevado. Entre esses morros e a borda da itha, uma generosa esplanada de topografia plana acolhe o sítio histórico da cidade de Santos (Figura 12). A barreira natural dos morros, além de facilitar a oferta de pedras para as edificações, defende a área dos ventos de sudoeste, associados às frentes frias, principalmente no inverno. Mas sua maior virtude ambiental, sem dúvida, verte de suas encostas: nascentes de água doce descomprometidas com a insalubridade marinha. Sem elas, não se fecharia o quadro ecológico possivelmente eleito como acampamento précolonial. Repete-se a paisagem das ocupações Tupi. E, ainda, a localidade está na conexão do canal de Bertioga. Ao longo do "rio de S. Vicente", não temos outro cenário pontual conjugado a tantos recursos.

Da praça da Matriz ao Carmo, nota-se o alinhamento da "rua direita"40. Sua extensão é o caminho pioneiro que, vindo de São Vicente, interligava as instalações agrárias da itha e encontrava o sítio portuário. Seu traçado certamente delineou a direção para onde a Matriz foi voltada, com a valorização do seu frontão pelas perspectivas de aproximação da vila.

Com status de "rua direita" no intraurbano, ela será vetor da expansão do núcleo, claramente sequenciado na cronologia de implantação dos conventos e igrejas do Carmo e de Santo Antonio; este, da Ordem dos Franciscanos.

\section{São Sebastião \& Ubatuba}

\section{"S. Sebastiam da Terra firme"}

Américo Vespúcio estava presente quando a expedição de Gonçalo Coelho batizou a itha de São Sebastião em homenagem ao Santo. Possivelmente arribaram na ampla enseada do setor norte, de onde provinham, e, ao adentrarem 


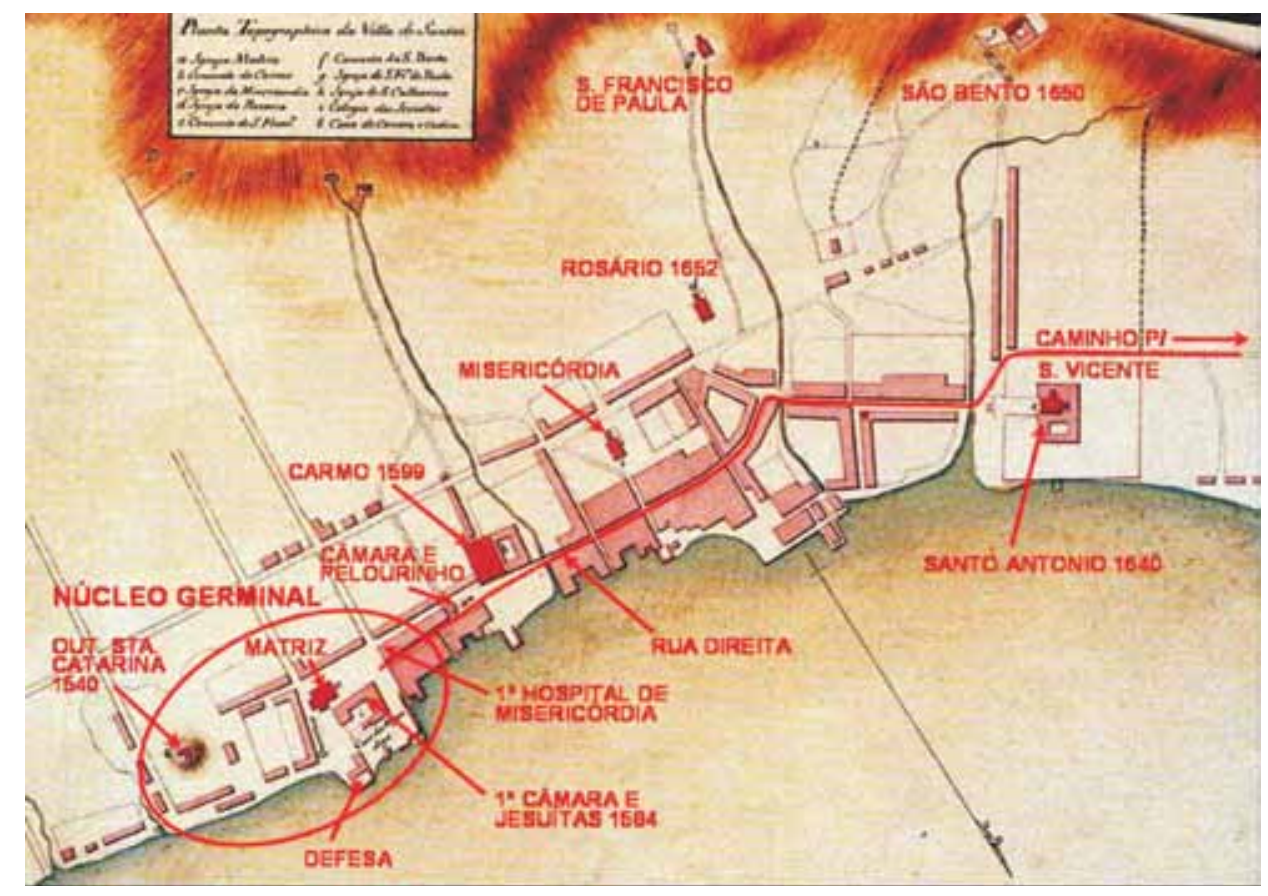

Figura 13 - Nova era. A restauração da capitania, em meados do XVIII, consolida o núcleo portuário. Infográfico elaborado pelo autor sobre detalhe da Planta Topographica da Villa de Santos. A imagem do final desse mesmo século mostra insinuações de expansão do tecido urbano. Fonte do mapa: Nestor Goulart Reis Filho (200 1a, p. 201).

pelo canal que a separa do continente, entenderam que se tratava de uma grande itha. Era 20 de janeiro de 1502. Talvez tenham aportado. Em condições normais, eles não levariam dois dias para chegar em São Vicente - batizada no dia 22 do mesmo mês -, como ocorreu. Quem sabe os encantos da paisagem e a serenidade portuária tenham motivado Gonçalo Coelho a lançar âncoras.

Mas quem conheceu bem a localidade de São Sebastião foi Hans Staden. Quando esteve no local pela primeira vez, amargava a certeza que morreria. Na manhã daquele dia, em meados de janeiro de 1554, foi aprisionado em Bertioga por guerreiros tupinambás. Caiu numa cilada imprevisível: nessa frente Tupiniquim, não era época de suas incursões guerreiras, habituais nos meses de inverno, quando disputavam a piracema dos cardumes de tainhas e paratis que adentravam no estuário vicentino. Levaram-no nas céleres canoas em direção aos seus domínios, localizados na baía de Angra dos Reis. Nessa viagem, pernoitaram no acampamento de São Sebastião. Antes, aportaram numa das praias da face interna da itha homônima,

pelas quatro horas da tarde, a julgar pelo sol - se dirigiram para uma itha e puxaram a canoa para a praia. Aí queriam passar a noite. A mim, arrastaram-me por terra. Eu não podia ver nada porque tinha o rosto machucado, e não podia andar direito por causa das feridas

Annals of Museu Paulista. v. 20. n.1. Jan.-Jun. 2012. 
41. Cf. Hans Staden (1974, p. 84).

42. Idem, ibidem.

43.Idem, ibidem; grifo nosso. na perna. Por isso precisei deitar-me na praia. Eles rodearam e davam-me a entender, com gestos ameaçantes, como iriam devorar-me ${ }^{41}$.

A figura do cronista deveria ser conhecida dos tupinambás. Era o responsável pela pequena fortaleza que terminou de construir, a serviço da Coroa, na barra de Bertioga, na porção norte da ilha de Santo Amaro. Além de terminar a construção, foi contratado para ali residir na defesa daquele canal. E talvez por isso tenha sido aprisionado. Suas lágrimas podem ter-the salvado. Conforme observou Darcy Ribeiro, os índios não comiam covardes para não incorporar suas mazelas. E o que Staden fez foi cantar "com os olhos úmidos de lágrimas, do fundo do coração, o salmo: 'Do abismo da miséria clamo eu a Ti'. Ao que disseram os selvagens: 'Vejam como ele grita; agora está desesperado." $42 \bigcirc$ prisioneiro deve ter percebido a força dos seus lamentos, pois, em seus nove meses e meio de cativeiro, sempre clamava por vida e por Deus quando as ameaças recrudesciam. No final daquela tarde,

então ponderaram que não seria conveniente passar a noite na ilha e aí acampar e dirigiram-se ao continente em frente. Já era noite, quando chegamos. Lá havia cabanas, que tinham construído antes. Arrastaram as canoas para a terra, fizeram fogo e deitaram-me perto. Devia dormir numa rede, que chamam ini. Estas são seus leitos ${ }^{43}$.

Parece bastante provável que o local deste acampamento seja o sítio da futura vila de São Sebastião. Trata-se de uma esplanada praiana que configura uma "ponta continental", onde se articulam os rumos da navegação costeira e onde o canal tem a menor largura em relação à ilha de São Sebastião. Devido ao menor percurso de marinha, este acampamento indígena pode ter sido embrionário dos sítios e caminhos de ocupação entre o continente e a ilha. Alguns morros no setor sul protegem o sítio das ventanias desse quadrante. Talvez por isso, naquele fim de tarde, os guerreiros tamoios buscaram melhor abrigo atravessando o canal, onde havia cabanas. A sede do atual município ocupa generosa planície costeira, a de maior amplitude nas adjacências, local em que a serra do Mar se debruça abruptamente no oceano. São condições ambientais atrativas às concentrações sociais, de qualquer período. $\bigcirc$ local beneficia-se de regatos de água doce, provenientes da encosta da serra do Mar; e o canal que separa a ilha do continente, pleno de águas calmas, tem profundidade suficiente para destinar-se a um grande porto.

A escolha de sítios praianos para acampamento é bastante aceitável pela temporalidade da ocupação e facilidade na puxada das canoas, permitindose diferenciar dos locais elevados que os tupinambás escolhiam para permanência das aldeias, estrategicamente mais protegidos. Nesses eventos passageiros, é bem provável que acampassem nas planícies adjacentes aos portos das canoas, envolvidos com a pesca e o preparo dos alimentos. Os acampamentos de São Sebastião e de Ubatuba eram representações dos meios ofensivos dos tupinambás, fronteiras espaciais e logísticas de suas áreas de ocupação. 
Iniciada no início do século por colonos de Santos requerentes de sesmarias na região, a povoação, foi elevada a vila em 1536. Atestando a ocupação embrionária, frei Gaspar da Madre de Deus informa:

E por isso começa da maneira seguinte o auto da criação desta Vila: "Anno do Nascimento de Nosso Senhor Jezus Christo de mil seis centos trinta seis annos aos desaseis dias do mez de Março do dito anno nesta povoaçam de S. Sebastiam da Terra firme, Termo, e Jurisdiçam da Villa de Santos da Capitania de S. Vicente" 44.

No início do século XVII, uma carta de sesmaria, de 20 de janeiro de 1603, afirma que: "na terra firme defronte dela [ilha de São Sebastião] e toda a costa até o Rio de Janeiro eram todas as terras desabitadas e devolutas"45. Nesse começo de século, inicia-se o povoamento do Litoral Norte com a instalação de engenhos de açúcar. Em Ubatuba, também foram requeridas sesmarias contemporâneas para o plantio da cana-de-açúcar.

Essas duas cidades do Litoral Norte paulista selaram identidades comuns, que remontam às ocupações tupinambás. $\bigcirc$ sequenciamento colonial é revelador do encadeamento espacial não só dos sítios urbanos, mas do contexto regional. As vilas foram fundadas com o mesmo propósito: resultaram da ocupação de um "vazio" litorâneo, da mesma forma que os Tamoio, com as "marcas territoriais" representadas pelos acampamentos, asseguravam a amplitude do habitat. Suas localidades estratégicas perpetuam-se no colonialismo. A paisagem ${ }^{46}$ recompõe-se após o encontro cultural entre europeus e indígenas, resgatando seus atrativos, seus "nichos ecológicos", suas articulações continentais e seus portos marítimos.

A Figura 14 é detalhe de uma Carta de São Sebastião, proveniente do levantamento que João da Costa Ferreira e Antonio Rodrigues Montesinhos elaboraram de toda a costa da capitania de São Paulo no final do século XVIII. É notável a condição de "pontal" do sítio, em relação ao canal fronteiro, acentuada pelo arco inferior do desenho que limita o núcleo. $\bigcirc$ levantamento identifica um dos córregos daquele espraiado praiano. Em todas as vilas estudadas, esses córregos estão presentes, muitas vezes vetorizando traçados urbanos, como em Cananeia e Santos.

Da mesma forma que Ubatuba, São Sebastião volta-se para o portal do mar. Ambas, todavia, parecem resguardar seus núcleos sociais, as praças, com relativo afastamento da orla. A concavidade marinha molda o arco de implantação do casario frontal, adequando a vocação portuária com a diretriz ambiental. Não deixa de revelar um desenho defensivo. A regularidade ortogonal, todavia, está presente nos módulos do binômio adro-igreja e projeta-se em cruz nos alinhamentos adjacentes. Essa imagem temporal do núcleo urbano de São Sebastião é bastante reveladora desse conceito, também verificado nas outras cidades estudadas. Os módulos germinais dos núcleos, atrelados ao(s) edifício(s) religioso(s), irradiam sua ortogonalidade na expansão urbana, até que os traçados sejam inexoravelmente tencionados pelas particularidades ambientais do tecido.
44. Cf. Frei Gaspar da Madre de Deus (1975, p. 182); grifo nosso.

45. Cf. Jurandyr Ferraz de Campos (2000, p. 68).

46. "A superfície da Terra é elaborada para cada pessoa pela refração por meio de lentes culturais e pessoais, de costumes e fantasias. Todos nós somos artistas e arquitetos de paisagens, criando ordem e organizando espaços, tempo e casualidade, de acordo com nossas percepções e predileções"; cf. Lucy Marion C. P. Machado (1986, p. 97). 


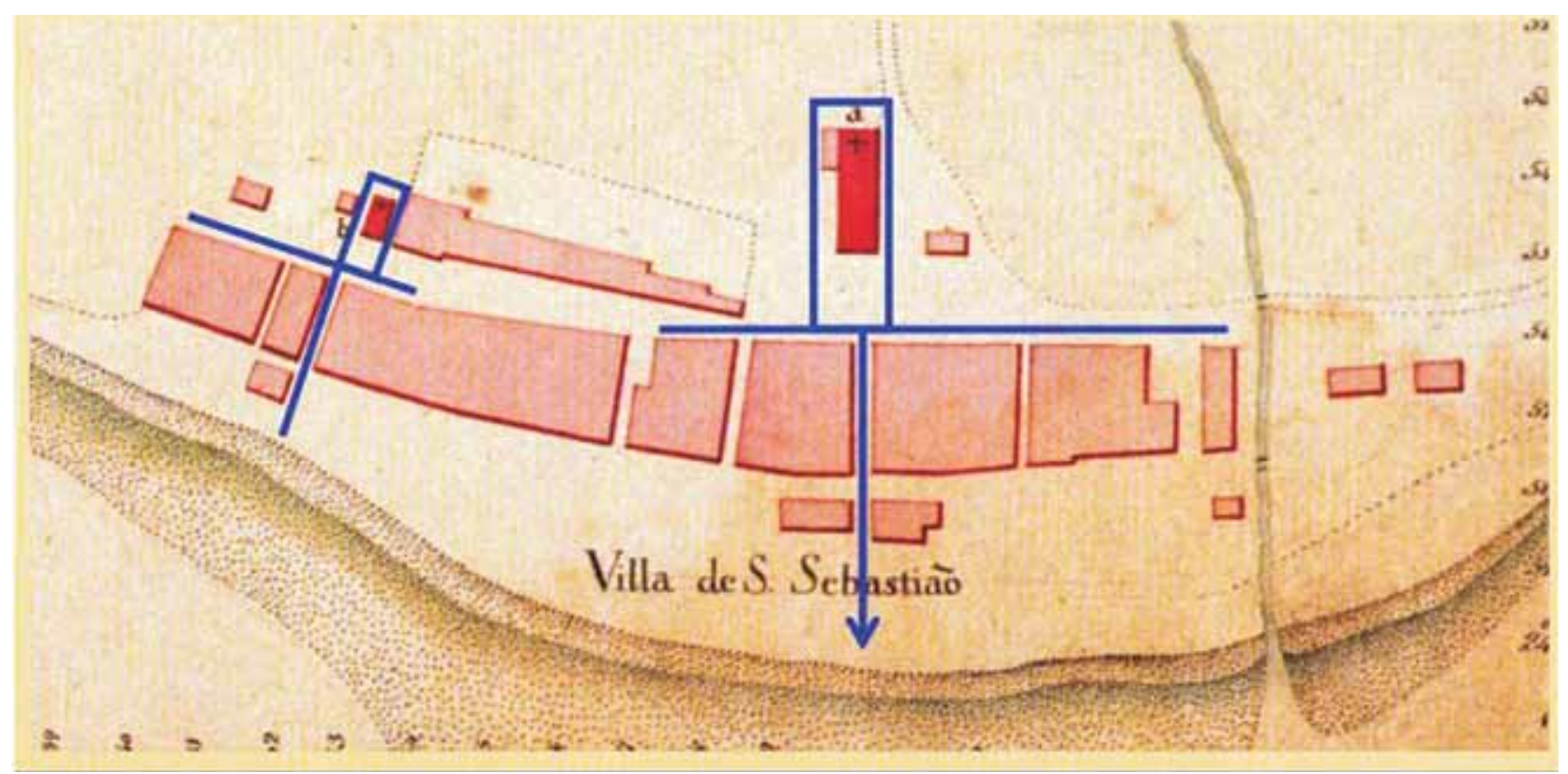

Figura 14 - A vila no pontal. Infográfico elaborado pelo autor sobre detalhe de uma das Cartas Corographicas e Hydrographicas..., de João da Costa Ferreira, 1815. Fonte do mapa: Nestor Goulart Reis Filho (200 1a, p. 202).

47. Ver nota 39.

48. Cf. Hans Staden (1974, p. 125).
Estas induzem à descontinuidade dos alinhamentos embrionários, relativizando a regularidade e, muitas vezes, a contiguidade prismática dos edifícios. $\bigcirc$ ambiente suplanta os rigores da geometria, e os desenhos dos núcleos coloniais revelam outra racionalidade: a adequação da arquitetura urbana aos seus sítios.

As zonas planas neste setor litorâneo são de pequena amplitude, intercaladas pela serra do Mar, que debruça seus contrafortes no oceano com poucas tréguas para ocupações humanas. Uma delas, das mais expressivas, é o sítio da vila. As encostas do maciço serrano balizam a circulação em caminhos de beira-mar que se alternam entre promontórios e praias. Decerto, na implantação do aglomerado, essa adjacência à orla foi angular, induzindo a diretriz da "rua direita", vetor de sua expansão urbana ${ }^{47}$. A articulação continental de São Sebastião, perpendicular à serra, é secundária: não está nessa direção o elo mais adequado da localidade com os atrativos regionais da bacia do Paraíba ou mesmo do Alto Tietê.

\section{"Vila Nova da Exaltação da Santa Cruz do Salvador de Ubatuba"}

Sobre Ubatuba, a primeira menção documentada que conhecemos é a descrição sutil deixada por Hans Staden sobre a localidade, ao passar por aí em meados de agosto de 1554. De tão singelo, o texto revela-se extremamente precioso: "Uma noite acampamos num lugar que também se chama Ubatuba. Aí apanhamos muito peixe, piratis ou tainhas, que são tão grandes como um lúcio bem desenvolvido. Soprava um vento forte" 48 . 


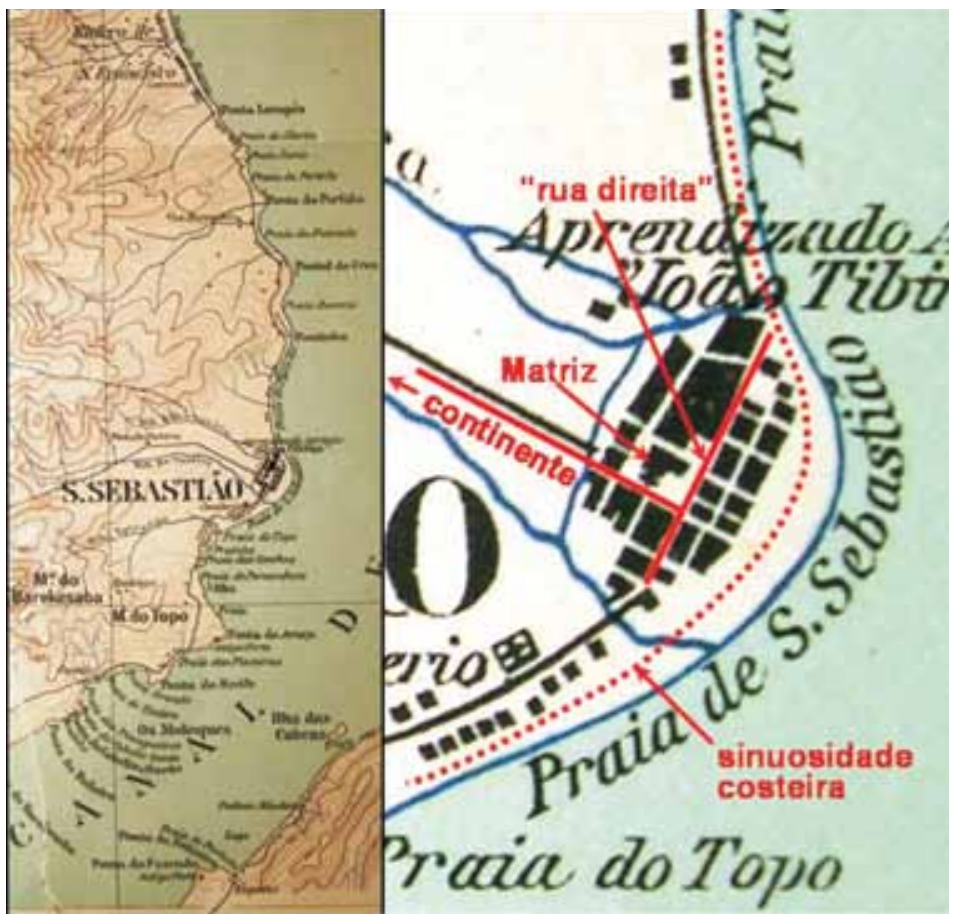

Figura 15 - Articulações. Infográfico elaborado pelo autor sobre detalhe da Planta do Litoral de S. Sebastião e do Rio Juqueriquerê. Fonte do mapa: Comissão Geographica e Geologica do Estado de São Paulo, 1915.

Livre do cativeiro, escreve sua aventura, editada em 1577. É notável que, com a memória ainda fresca, refere-se ao "lugar" onde "acampamos" e não menciona a existência de aldeias. Se existissem, seria omissão pouco provável não descrevê-las. $\bigcirc$ cronista mercenário, atento com as possibilidades de fuga, foi minucioso na descrição dos acampamentos, dos grupos locais e de todo o contexto espacial Tupinambá. Outra fonte etno-histórica, citada mais adiante, comprova que duas aldeias são encontradas na localidade de Ubatuba cerca de nove anos após o pernoite de Staden. Não podemos deixar de supor que, em 1563, quando os jesuítas Manuel da Nóbrega e José de Anchieta desembarcaram ali, eram ocupações recentes. Refletiam o crescimento demográfico da sociedade indígena ou as tensões provocadas, desde 1555, pela presença francesa na baía da Guanabara, região onde se concentrava a maioria dos grupos locais Tupinambá (ou Tamoio). Estavam aguçados os conflitos entre essa tribo, aliada dos calvinistas, e os portugueses, associados aos seus seculares inimigos Tupiniquim. Este cenário Staden não assistiu. Deixou o Brasil em 31 de outubro de 1554. Mas a real ameaça que a Confederação dos Tamoios representava para São Vicente, certamente fomentada pelos aliados da "França Antártica", recrudesceu a ponto de os inacianos se arriscarem a negociar em lperoig, outra denominação da localidade de Ubatuba. A perspicácia do padre Nóbrega foi precisa. Estabeleceu um diálogo no arco perimetral da tribo, com o objetivo claro 
49. Cf. Darcy Ribeiro e Carlos de Araújo Moreira Neto (1993, p. 260).

50. Esta carta, enviada para o geral dos jesuítas residente em Roma, foi escrita em São Vicente, no dia 8 de janeiro de 1565 .

51. Cf. Darcy Ribeiro e Carlos de Araújo Moreira Neto (1993, p. 259); grifo nosso.

52. Idem, p. 257; grifo nosso.

53. Ver Maria Cristina Scatamacchia e Dorath Pinto Uchoa (1993). de atenuar o foco guerreiro do Rio de Janeiro. Os portugueses não tiveram sucesso no envio de uma esquadra para derrotar os franceses em 1560. Nóbrega entendeu que o projeto colonial português corria sérios riscos com os tupinambás confederados. E acertou no alvo. Os caciques de Ubatuba (Pindobuçu e Cunhambebe) cederam aos argumentos dos hábeis catequizadores e iniciou-se um processo de negociações em lperoig. $\bigcirc$ provincial com alguns guerreiros viajam a São Vicente e ltanhaém na busca de entendimentos, enquanto Anchieta, refém em Ubatuba, amarga as incertezas do seu destino: "cada dia bebíamos muitos tragos de morte" 49 . O episódio na região é conhecido como a Paz de Iperoig. Na verdade foi uma trégua ardilosa até as forças portuguesas se recomporem, com forte participação de Nóbrega, para lograr a expulsão dos franceses e o extermínio Tupinambá, motivando a fundação do Rio de Janeiro em 1565. Na esteira das ações dominadoras, os Tamoio remanescentes, refugiados em Cabo Frio, são aniquilados em setembro 1575.

A Carta ao padre Diogo Laines ${ }^{50}$, em que Anchieta registra sua estada em Ubatuba, informa-nos sobre a existência de duas aldeias, dando indicação precisa do local da principal delas, a do cacique Pindobuçu: "todavia correu quanto pode, e mais do que pôde, até o fim da praia, onde, antes da aldeia, que está posta em um monte mui alto, corre uma ribeira d'água mui larga e que dá pela cintura" ${ }^{\prime \prime}$.

No escopo do documento não há referência sobre a localização do sítio da outra aldeia. Mas, em outras passagens da carta, deixa transparecer que não ficavam distantes, ocupando as adjacências do mesmo recorte costeiro. Logo que desembarcam na enseada de Ubatuba llocalidade à qual se refere como "primeiros lugares dos inimigos" ou mais significativamente como "aquela fronteira"), comenta que "Chegados à praia [...] Visitamos ambas as aldeias"52.

Além do sugerido enquadramento das duas aldeias na mesma enseada, há uma importante pesquisa arqueológica que contribui para a suposta localização do sítio da segunda aldeia, em harmonia com os indícios deixados por Anchieta. Trata-se da identificação do local denominado Sítio do Itaguá, no mesmo entorno praiano que foi palco da permanência dos jesuítas em 1563.

As pesquisadoras Maria Cristina Scatamacchia e Dorath Pinto Uchoa, em estudo publicado em 1993, identificam no Sítio do Itaguá evidências da ocupação Tupi (restos de fogueira, grande quantidade de carvão, buracos de estacas, restos de um sepultamento e material cerâmico) e artefatos de procedência europeia (4 contas de vidro, 1 pequeno disco de cobre $)^{53}$.

Entre a narrativa etno-histórica e a pesquisa arqueológica, parece razoável, pela coerência de seus relatos, a hipótese do "Sítio de Itaguá" corresponder à segunda aldeia encontrada por Anchieta. No contexto dos grupos locais Tupinambá, instalados em acrópoles, tangenciados pelos corpos d'água principais da região e com visão de $360^{\circ}$ do entorno, principalmente do mar, há ainda outro local - na mesma enseada, com as mesmas qualificações ambientais - que poderia ser aceitável como sua localização. Atualmente está edificado e 
não há nenhum registro documental que comprove sua ocupação pregressa por aldeia indígena (Figura 16).

A identificação da aldeia do cacique Pindobuçu e as descobertas arqueológicas do Sítio de Itaguá reiteram os critérios litorâneos de ocupação Tupi. Estão presentes o agenciamento à rede fluvial, a proximidade das matas e de terras férteis para os cultivos e para lenha, a abundância de peixes e a condição portuária de enseada abrigada, adequada aos seus meios, com a particularidade de que "A localização alta na maioria dos sítios, propiciando uma boa visão dos arredores e defesa mais fácil, parece indicar um clima bastante belicoso"54. A esse contexto ecológico acrescenta-se a inserção da localidade na paisagem regional.

O panorama geográfico decerto contribuiu para as escolhas de ocupação; é um dos vetores da composição ambiental das intrínsecas vivências indígenas. Da baixada santista para o norte (na verdade, direção nordeste), até a
54. Cf. André Prous (1992, p. 387).

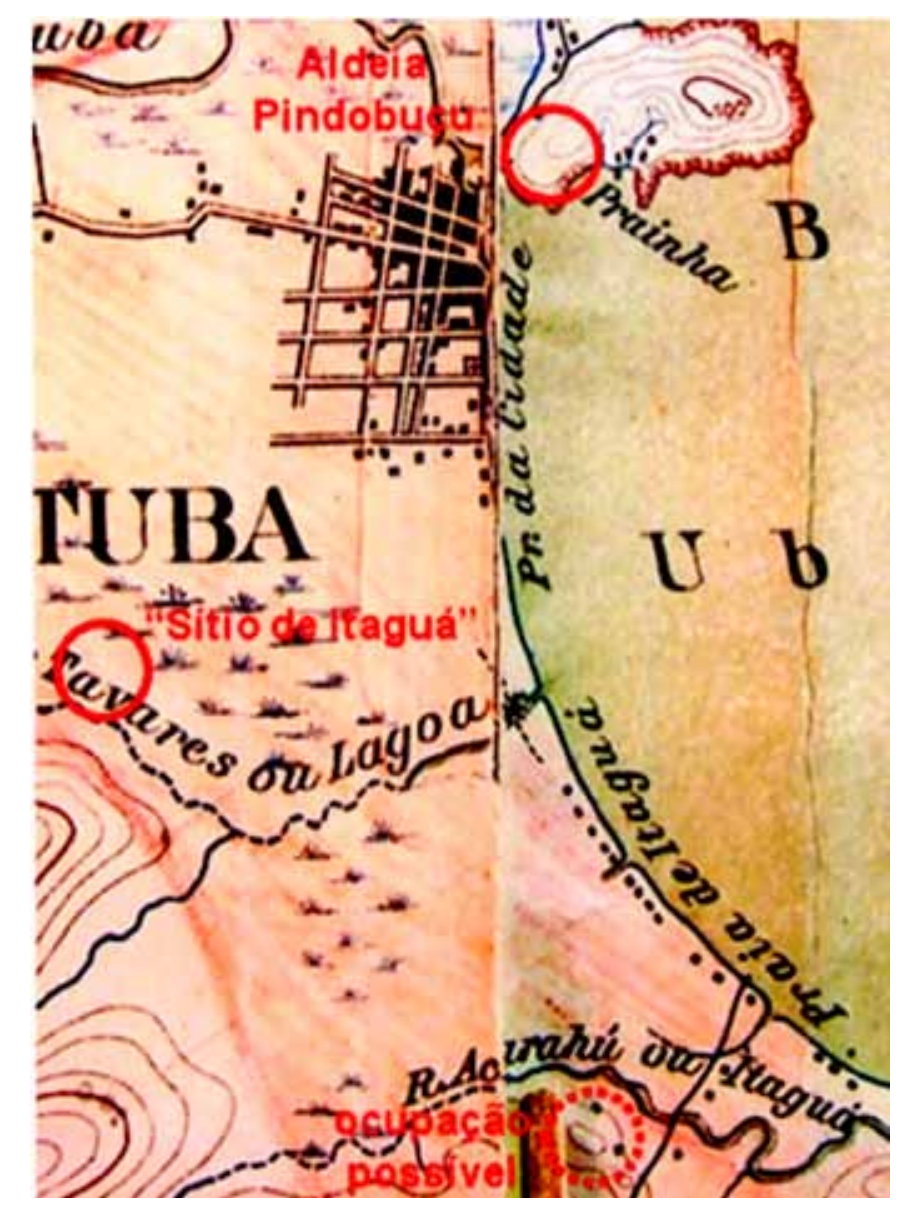

Figura 16 - Aldeias. Infográfico elaborado pelo autor sobre detalhe da Planta entre a Enseada de Caraguatatuba e a Praia de Itamambuca. Fonte: Comissão Geographica e Geologica do Estado de São Paulo, 1915. 
55. Cf. Washington de Oliveira (1977, p. 44).

56. Cf. Nestor Goulart Reis Filho (2001b, p. 558). baía da Guanabara, a serra do Mar mantém um perfil homogêneo em relação à linha litorânea. Seus contrafortes abruptos, de escarpas festonadas, com altitudes de até mil metros, muitas vezes se debruçam nas águas da marinha, limitando as planícies costeiras a trechos de pouca expressão. Este relevo de recortes proporciona pequenas enseadas abrigadas de ventos e de correntes marítimas, com praias de pequena amplitude em cenários de extrema beleza. Assim ocorre na área central do atual município de Ubatuba e em outras localidades da vizinhança (Maranduba, Rio Escuro, Itamambuca, Ubatumirim etc.). Essas planícies, por sua relativa extensão e maior capacidade de drenagem, oferecem os rios mais expressivos dessa costa. O Rio Grande de Ubatuba, com estuário na sede da cidade e no sopé da antiga Aldeia de Pindobuçu, seria por si só um atrativo especial para ocupação desse recorte costeiro. Um segundo fator soma-se a este referencial: as vertentes de suas cabeceiras, por sua escala, recortam significativamente o contraforte serrano nessa latitude. Tal particularidade do relevo favorece o acesso ao planalto, pela maior amplitude linear do plano inclinado da costa. Estes "recortes em cunha" no relevo serrano, não por acaso, foram apropriados aos "peabirus", aos caminhos, às estradas de ferro e rodagem e, atualmente, às nossas rodovias. São os cenários geográficos que disponibilizaram as articulações entre o planalto e o nosso litoral. O de Ubatuba é típico, mas é também o que ocorre na Baixada Santista, em Caraguatatuba, em Parati e em Angra dos Reis (Figura 2). Um terceiro fator, ainda, complementa a escolha de Ubatuba: no acesso facilitado ao planalto por esta diretriz, estão os rios Paraibuna, Paraitinga e, no fundo do vale, o Paraíba: esta rica rede fluvial, paisagem típica dos povos Tupi-Guarani, além de apontar para os domínios Tupiniquim, complementava os "nichos" ecológicos litorâneos pela diversidade de recursos naturais.

Quando Jordão Homem da Costa veio fundar a vila Nova da Exaltação da Santa Cruz do Salvador de Ubatuba - por Provisão de 28 de outubro de 1637, de Salvador Correa de Sá e Benevides, governador do Rio de Janeiro -, a localidade era "um ermo..." 55 . Por isso mesmo teve liberdade de escolher um sítio para sua fundação que viesse ao encontro de sua intenção colonizadora. Não teve dúvida em agenciá-lo na mesma localidade de escolha Tupi. Estava ali o mesmo rio, a mesma planície costeira, o mesmo abrigo portuário, a mesma enseada acolhedora e a mesma diretriz de acesso ao planalto. Só não ocupou o mesmo altiplano da aldeia, não havia razão para isso: eram novos programas sociais. A zona plana da praia era convidativa às instalações das novas tipologias de arquitetura urbana. "Não há dúvida de que a adesão, quase total, aos critérios de escolha de sítios planos, para instalação dos núcleos urbanos, pode ter sido um estímulo significativo para o uso de traçados mais regulares" 56 . Sua fundação, significativamente contemporânea à de São Sebastião (1636), foi uma decisão que teve a chancela da coroa, naqueles tempos unificada.

Por volta de 1791 - data do levantamento do providencial mapa urbano elaborado por João da Costa Ferreira e Antonio Rodrigues Montesinhos -, Ubatuba era, talvez, de todos os núcleos urbanos do litoral da capitania de São Paulo, o mais modesto. Sua extensão correspondia ao entorno da Matriz, e 
deixa transparecer um mínimo da racionalidade que remonta à gênese fundadora, expresso pela própria imagem. Vemos, todavia, um alinhamento de traçado sinuoso junto à praia que se estende pela zona plana em direção ao rio da Lagoa (Figura 17). Sugere um caminho pregresso ao evento urbano, provavelmente articulador de ocupações, dispersas na região, de produção rural ou mesmo das remotas instalações indígenas. Reflete o atrativo do porto, com pequenas edificações isoladas, sem a contiguidade marcante do módulo central. Parecem vinculadas à pesca, ou a instalações anteriores ao relativo formalismo do núcleo colonial. A pequena igreja extinta (c, à esquerda), de invocação à Nossa Senhora da Conceição, localizada na borda desse caminho, talvez confirme a tradição oral de ser anterior à Matriz, essa sim atrelada à fundação da vila. Pode ter raiz na cristianização que sucedeu à pacificação dos tamoios. Outro vetor de articulação insinua-se no traçado posterior da Matriz. Trata-se da diretriz secular que, perpendicular à praia, estende-se do sítio aos contrafortes da serra, alcançando o planalto. A imagem da Figura 17 insinua o alinhamento contínuo no lado direito do desenho. No tracejado da Figura 18, compreendemos que a rua Direita de Ubatuba (assim denominada até meados do século XX) sequenciava o alinhamento sinuoso pregresso, interceptada na expansão urbana do século XIX (similar a Cananeia), quando o café mudou a paisagem do Vale do Paraíba.

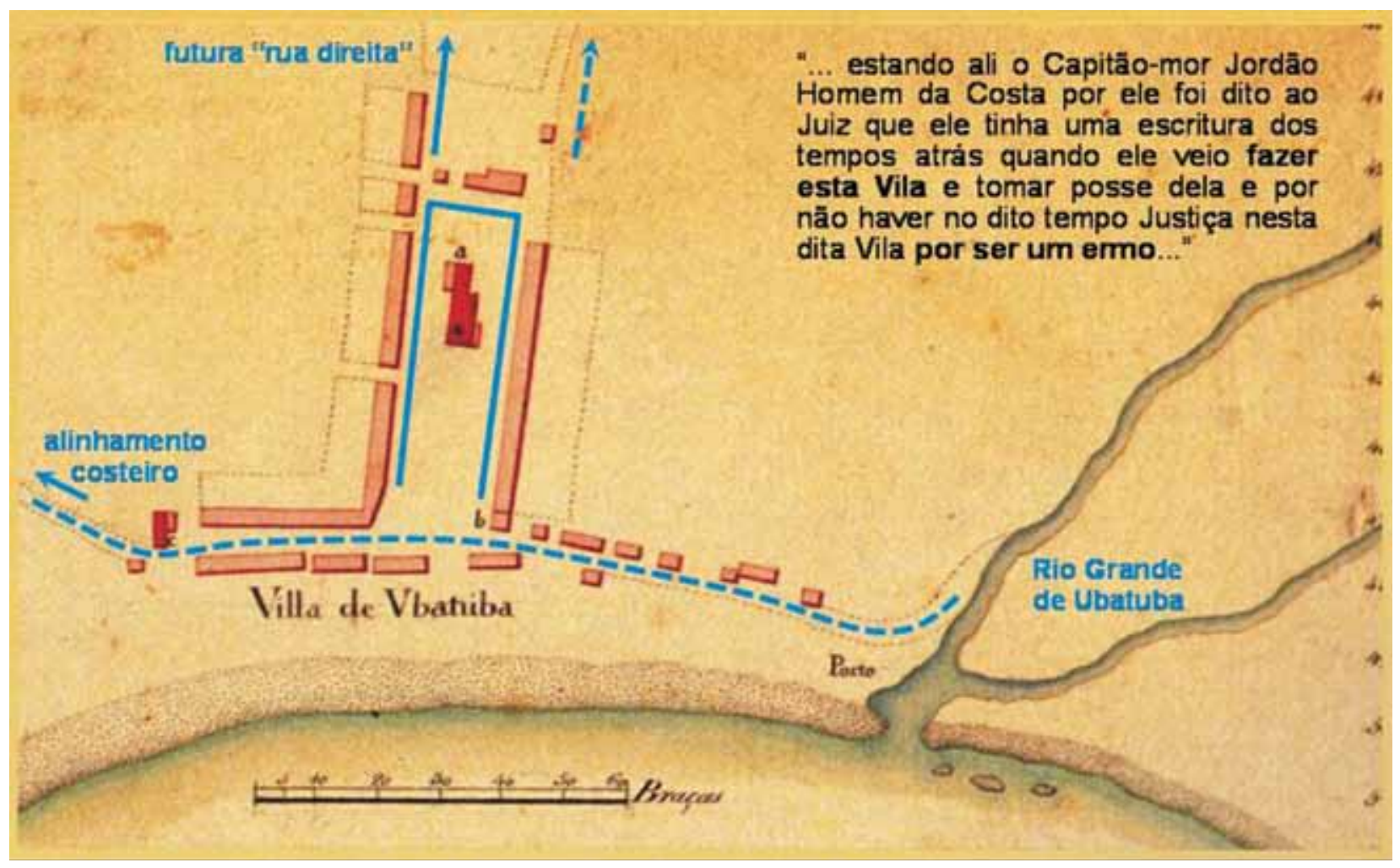

Figura 17 - Vila praiana. Infográfico elaborado pelo autor sobre detalhe de uma das Cartas Corographicas e Hydrographicas..., de João da Costa Ferreira, 1815. Fonte do mapa: Nestor Goulart Reis Filho (200 1a, p. 202). 


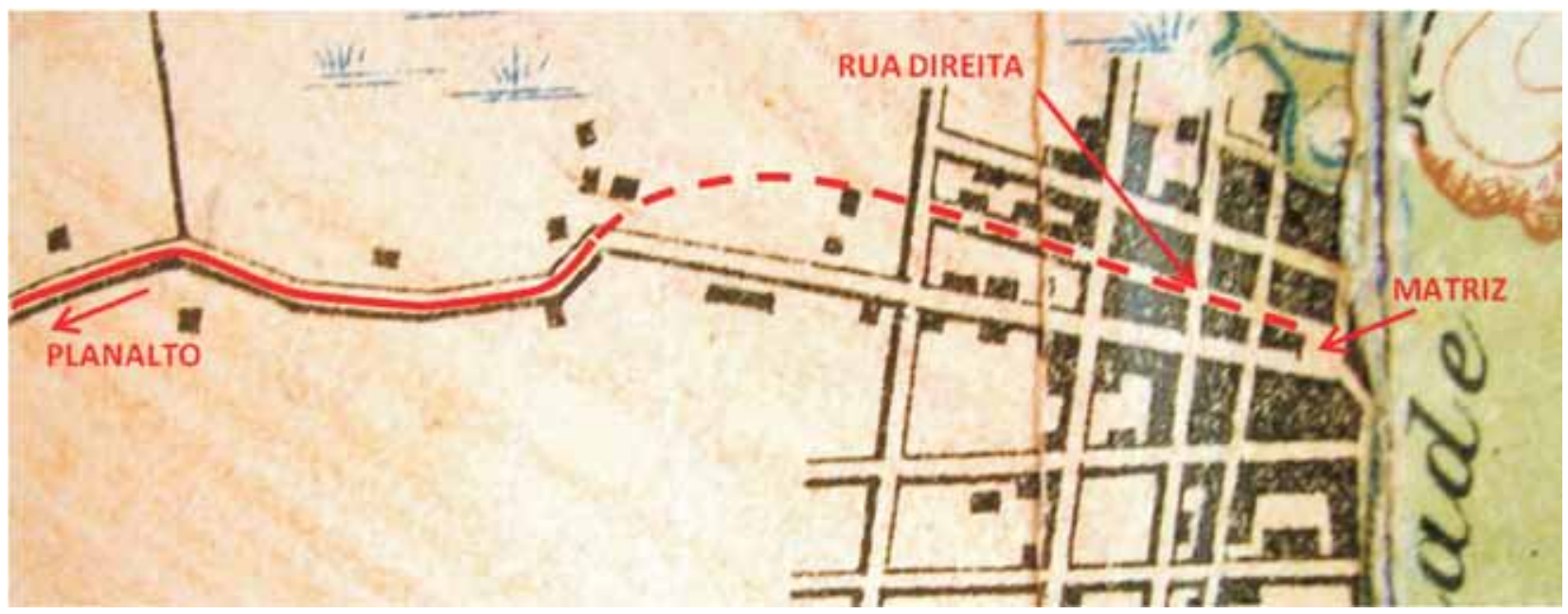

Figura 18 - Adequações. Infográfico elaborado pelo autor sobre detalhe da Planta entre a Enseada de Caraguatatuba e a Praia de Itamambuca, mencionada. Fonte do mapa: Comissão Geographica e Geologica do Estado de São Paulo, 1915.

57. Cf. Yi-Fu Tuan (1980, p. 107). fato é que a direção das vertentes do rio Grande de Ubatuba para o alcance do planalto corresponde, em todos os tempos, a uma das principais justificativas de escolha desse sítio para ocupação.

\section{Direitas \& Retas}

Os espaços construídos são testemunhos de identidades históricas. Entre percursos sinuosos e retilíneos, a imagem de nossas vilas litorâneas revela, antes de tudo, harmonia na escala dos edifícios, na amplitude dos vazios, na densidade de ocupação e, sobretudo, na inserção ambiental. Impossível dissociálas das raízes pré-coloniais. No intraurbano, o diferencial tortuoso das ruas direitas sugere o encantamento das antigas trilhas, dos caminhos pelos melhores contornos, do desvio das águas, dos morros, das serras. Por isso sua sinuosidade é reveladora. Seu traçado reproduz a naturalidade da interação ambiental dos antigos habitantes. Esses logradouros especiais não são para partidas - são terminais de articulação continental. E ficaram estampados talvez na maioria do desenhos das vilas e cidades do colonialismo. Representam as ocupações anteriores, expressão simbólica da vertente cultural indígena em nossas produções urbanas. Da mesma forma, simbolizam a aceitação e a incorporação dos vetores antigos pelo colonizador. A harmonia ambiental dos seus traçados com as determinantes geométricas da arquitetura ibérica é síntese do encontro cultural. $\bigcirc$ enlace dessas vertentes sociais manifesta novas feições.

Ao contextualizarmos a vivência cultural dos habitantes do passado na produção dos seus espaços, apropriamo-nos do conceito de "topofilia", criado pelo geógrafo humanista Yi-fu Tuan. Trata-se, de forma simplista, do "elo afetivo entre as pessoas e os lugares" 57 , o que diz muito. As representações espaciais históricas espelham as percepções, os pensamentos, as atitudes e as emoções 
dos homens do passado. $\bigcirc$ catolicismo determinante do colonizador envolvia todos os segmentos culturais: desde a educação às festividades; da devoção espiritual aos compromissos materiais; das práticas religiosas aos controles civis. Não é de se estranhar, nas paisagens urbanas do colonialismo vicentino, a proeminência da arquitetura religiosa em relação ao espraiado de casarios modestos, no máximo assobradados. Os espaços públicos, além de propiciar a circulação, eram os meios de comunicação, o palco das informações e das convivências, intensificadas nas festividades do calendário litúrgico.

Traduzidos em suas representações espaciais e independentes de suas escalas primárias, especialmente em sítios planos, os edifícios religiosos irradiam sua ortogonalidade arquitetural no traçado das ruas, adros, largos ou futuras praças do seu entorno. Estas linhas, portanto, são balizadoras do desenho urbano em suas evoluções. Nas vilas estudadas, observamos a reprodução desse modelo. Espelha a imponência da cultura religiosa fortemente atrelada ao Estado português no colonialismo. O caso de Santos (Figura 19) é referencial.

Os adros demandavam terrenos generosos, intrínsecos às igrejas. $\bigcirc$ volume edificado e seu vazio frontal configuram o que poderia ser entendido como um binário espacial: um módulo urbano composto da interação de dois espaços,

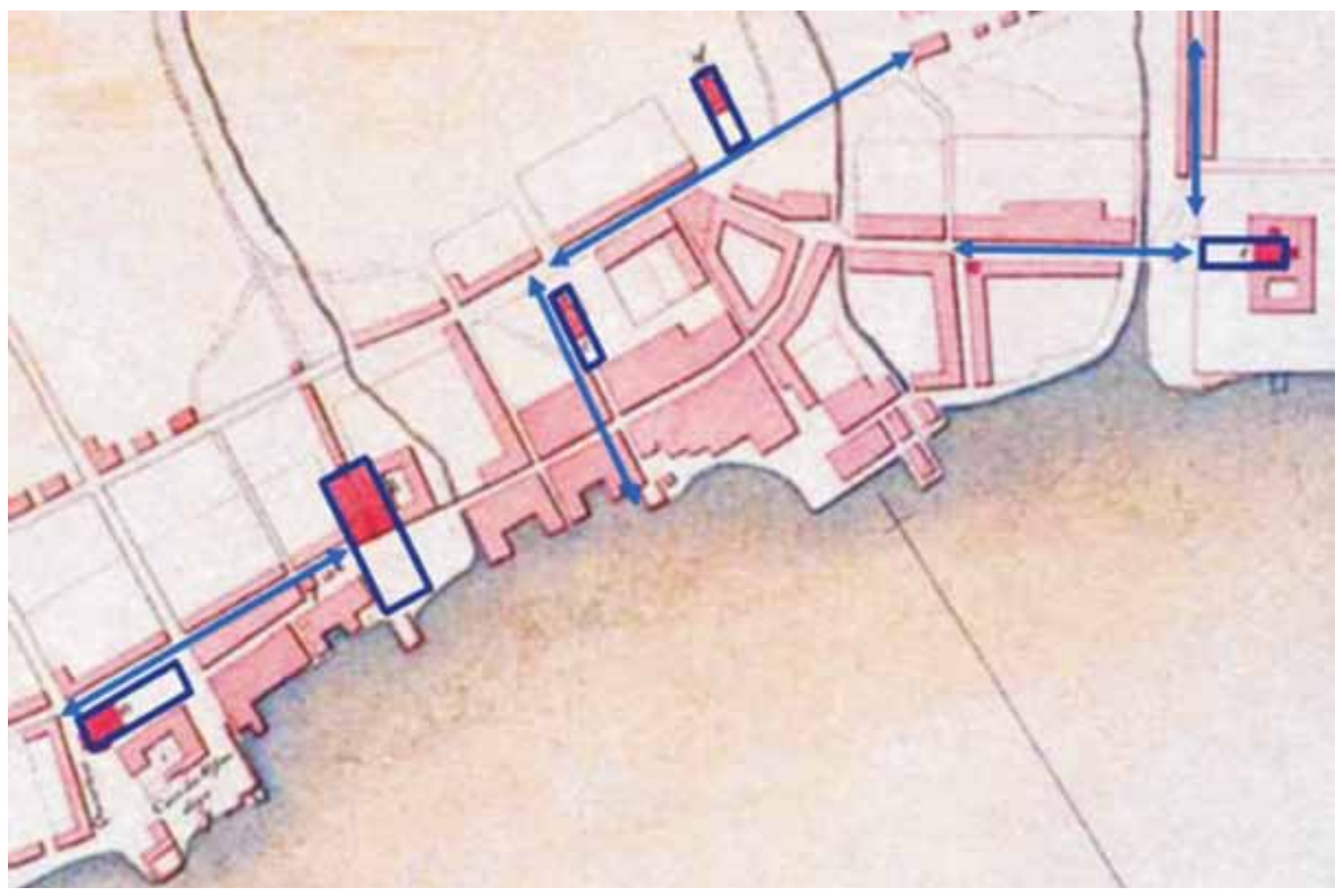

Figura 19 - Os nós articuladores do tecido. Os edifícios religiosos, módulos espaciais implantados gradativamente, irradiam ortogonalidade no entorno. Infográfico elaborado pelo autor sobre detalhe da Planta Topographica da Villa de Santos. Fonte do mapa: Nestor Goulart Reis Filho (2001a, p. 201). 
58. Idem, p. 148.

59. Ver Pasquale Petrone (1995).

60. Cf.John Manuel Monteiro (1994, p. 56). diferenciados nas compleições, mas indissociáveis nas funções. Complementam-se na consagração do domínio espiritual: no interior introspectivo, o cerimonial, o diálogo com os santos e com Deus; no exterior festivo, a extensão das amplitudes visuais de contemplação do sagrado, da cruz, dos frontões ornamentados, das torres - do "cosmo vertical" citado por Tuan ${ }^{58}$.

Num povoado germinal, essa concepção seguramente compromete o desenho da futura expansão urbana. E quando se trata de implantações que decorrem em tecidos já consolidados, a recíproca também é verdadeira. $\mathrm{Na}$ inserção de novos módulos (atrelados a outras ordens religiosas, em resposta à complexidade social evolutiva do núcleo), o tecido urbano, na trajetória de sua expansão, agenciará esses "elementos marcantes", adequando o prisma arquitetural na contiguidade dos seus alinhamentos. São nós articuladores do tecido urbano, que transparecem nos traços de regularidade das vilas litorâneas. Nesses sítios, incomum será se as faces prismáticas do edifício religioso não balizarem os alinhamentos das ruas adjacentes, ou se não forem balizadas por elas.

O enquadramento no sítio e na paisagem - seja da ermida, da capela, da igreja ou da futura matriz - responde a seu significado simbólico. Sua proeminência nos núcleos coloniais talvez deixe transparecer a enorme tarefa de se conduzir, para as vertentes comuns do catolicismo e do poder central, uma sociedade de raízes culturais tão diversificadas.

Os missionários, principalmente os jesuítas, defenderam seus catecúmenos como entenderam e puderam, concentrando-os nos "aldeamentos paulistas" reivindicavam da corte medidas protetivas, que, todavia, não intimidavam os interesses colonialistas. Foi um jogo de forças onde o índio sempre perdeu. Foram desintegrados dos cenários seculares de sua vivência, especialmente pelas guerras e doenças dos brancos: "Até o fim do século, grande parte do território antes ocupado pelos Tupiniquim e Guaianá encontrava-se seguramente em mãos dos conquistadores" 60 . Mas sua herança ficou fortemente incorporada na produção dos espaços da nova sociedade constituída após o encontro cultural com os europeus que aqui chegaram. Os processos de ocupação subsequentes não foram dissociados das escolhas antigas. Ao contrário, lograram êxito enquanto respeitaram suas localidades e seus caminhos de articulação territorial. Mais do que balizar as instalações incipientes do colonialismo, os lugares indígenas de vivência justificaram a configuração da rede urbana brasileira - que, ao que parece, foi sendo, ao longo dos séculos, sedimentada e ampliada acenando recorrentemente aos mesmos critérios de ocupação, da frente litorânea aos horizontes continentais.

\section{REFERÊNCIAS}

AB'SABER,Aziz N. Litoral do Brasil. São Paulo: Metalivros, 2005.

ALMEIDA,Antonio Paulino de.A ilha de Cananeia. Revista do Arquivo Municipal, São Paulo, a. 19, v. 154, p. 3-12, 1952. 
AZEVEDO,Aroldo de. Vilas e cidades do Brasil colonial. São Paulo: FFCL-USP, 1956 (Geografia, 11; Boletim, 208).

BUENO, Beatriz Piccolotto Siqueira. Dilatação dos confins: caminhos, vilas e cidades na formação da Capitania de São Paulo (1532-1822). Anais do Museu Paulista, São Paulo, v. 17, n. 2, p. 251-294, jul.-dez. 2009 [Nova série].

BURKE, Peter. O que é história cultural? Rio de Janeiro: Zahar, 2005.

CAMPOS, Jurandyr Ferraz de. Santo Antônio de Caraguatatuba. Caraguatatuba: Fundacc, 2000.

COMISSÃO GEOGRAPHICA E GEOLOGICA DO ESTADO DE SÃO PAULO. Exploração do littoral: 1. Secção. Cidades de Santos, a fronteira do Estado do Rio de Janeiro. São Paulo:Typographia do Brazil de Rothschild \& Co., 1915.21p. (Inclui fotos e mapas).

Exploração do littoral: 2. Secção. Cidades de Santos a fronteira do Estado do Rio de Janeiro. São Paulo:Typographia do Brazil de Rothschild \& Co., 1920. 13p. (Inclui fotos e mapas).

FERNANDES, Florestan. Organização social dos Tupinambá. São Paulo: Difusão Europeia do Livro, 1963.

FUNARI, Pedro Paulo; NOELLI, Francisco Silva. Pré-história do Brasil. São Paulo: Contexto, 2005.

HOLANDA, Sérgio Buarque de. Raízes do Brasil. 6. ed. Rio de Janeiro:José Olympio, 1971.

LUÍS, Washington. Na capitania de São Vicente. São Paulo: Edusp, 1980.

MACHADO, Lucy Marion C. P. A paisagem valorizada: a serra do Mar como espaço e como lugar. In: RIO, Vicente del; OLIVEIRA, Lívia (Org.). Percepção Ambiental: a experiência brasileira. São Carlos: EdUFSCar, 1986. p. 97-119.

MADRE DE DEUS, Frei Gaspar da.Memórias para a bistória da Capitania de São Vicente. Belo Horizonte: Itatiaia; São Paulo: Edusp, 1975.

MONTEIRO, John Manuel. Negros da terra: índios e bandeirantes nas origens de São Paulo. São Paulo: Companhia das Letras, 1994.

NEME, Mário. Notas de revisão da bistória de São Paulo. São Paulo:Anhambi, 1959.

ODUM, Eugene Pleasants. Fundamentos de ecologia. Lisboa: Fundação Calouste Gulbenkian, 2004.

OLIVEIRA, Washington de. Ubatuba documentário. São Paulo: Editora do Escritor, 1977.

PETRONE, Pasquale. Povoamento e caminhos nos séculos XVI e XVII. In: A Baixada Santista: aspectos geográficos, Vol. II, São Paulo: Edusp, 1965. Cap 6 ${ }^{\circ}$ p. 11-73.

Aldeamentos paulistas. São Paulo: Edusp, 1995.

PROUS,André. Arqueologia brasileira. Brasília: Editora da UnB, 1992

REIS FILHO, Nestor Goulart. Evolução Urbana do Brasil. São Paulo: Edusp, 1968.

Imagens de vilas e cidades do Brasil colonial. São Paulo: Edusp, 2001a.

Annals of Museu Paulista. v. 20. n.1. Jan.-Jun. 2012. 
.Vilas paulistas do século XVII. In: COLÓQUIO INTERNACIONAL UNIVERSO URBANÍSTICO PORTUGUÊS 1415-1822, 1999, Coimbra. Actas... Lisboa: CNCDP, $2001 \mathrm{~b}$.

RIBEIRO, Darcy. O povo brasileiro. São Paulo: Companhia das Letras, 1995.

; MOREIRA NETO, Carlos de Araújo. A fundação do Brasil. Petrópolis:Vozes, 1993.

ROSSA, Walter. A cidade portuguesa. In: PEREIRA, Paulo (Dir.). História da arte portuguesa, 3. Barcelona: Círculo de Leitores, 1995. p. 233-323.

SCATAMACCHIA, Maria Cristina Mineiro. A tradição policrômica no leste da América do Sul evidenciada pela ocupação Guarani e Tupinambá: fontes arqueológicas e etno-históricas. 1990. Tese (Doutorado em Antropologia Social) - Departamento de Antropologia da Faculdade de Filosofia, Letras e Ciências Humanas da Universidade de São Paulo, São Paulo, 1990.

. Seminário Cananeia tem história, 1. Cananeia: Prefeitura Municipal de Cananeia, 2005.

; UCHÔA, Dorath P.O contato euro-indígena visto através de sítios arqueológicos do estado de São Paulo. Revista de Arqueologia. São Paulo, n. 7, p. 153-173, 1993.

SCHADEN, Egon. Os primitivos habitantes do território paulista. Revista de História, São Paulo, v. 5, n. 18, p. 385-406, abr.jun. 1954.

STADEN, Hans. Duas viagens ao Brasil. Belo Horizonte: Itatiaia; São Paulo: Edusp, 1974.

TUAN, Yi-Fu. Topofilia. São Paulo: Difel, 1980.

YOUNG, Ernesto G. Subsídios para a história de Iguape. Revista do IHGSP, São Paulo, v. 2, p. 286$375,1902$.

Artigo apresentado em 1/201 1. Aprovado em 12/201 1. 